\title{
Teaching of Speaking Skill with Picture Expression Strategy at the تعليم مهارة الكلام باستراتية التعبير المصور في المعهد العصري /slamic Boarding School الإسلامي
}

\author{
Anisatul Barokah, Zamronah Rizqiyah \\ IAIN Surakarta \\ nisekapoor@yahoo.com
}

\begin{abstract}
The purpose of this study was to determine the implementation of the strategy atta'bir almushawwar using the book Muthala'ah alqiro'ah al-rosyidah and to determine the increase in speaking skills. This research uses qualitative research. This research was carried out from June to August 2019 at the Islamic Boarding School Ta'mirul Surakarta. The data collection techniques are through interview, observation, and documentation techniques. And the data validity technique uses triangulation of sources and methods. And data analysis techniques using data collection, data reduction, data presentation, and draw conclusions. The results of the study show that the steps of atta'bir almushawwar using the Muthala'ah alqiro'ah alrosyidah book, namely the teacher reads the vocabulary aloud and students follow it, and the teacher asks students to interpret it, the teacher asks the students to listen to the teacher's explanation with Image media are on the board and in a situation where students do not open the book, the teacher asks students to read muthalaah books and then gives students time to ask questions about vocabulary or things that have not been understood, the teacher asks some students to retell what the teacher has explained in front of the class by using Arabic. By using the attakbir almushawwar strategy in learning the muthalaah book, it is very helpful for students to remember the material that has been explained by the teacher. Because the explanation using image media makes students interested so that students pay attention to the scale of what is explained by the teacher. And in addition students have to memorize again using Arabic that they have understood, with this students are trained in speaking and can increase students' speaking skills
\end{abstract}

Keywords: Atta'bir Almushawwar's, speaking skills, Muthalaah, Al Qiroah Al rasyidah.

\section{ABSTRAK}

Tujuan penelitian ini adalah untuk mengetahui pelaksanan strategi atta'bir almushawwar dengan menggunakan kitab Muthala'ah alqiro'ah al-rosyidah dan untuk mengetahui peningkatan maharah kalam. Penelitian ini menggunakan penelitian kualitatif. Pelaksanaan penelitian ini pada bulan juni sampai agustus 2019 di pondok Pesantren Ta'mirul Islam Surakarta. Adapun teknik pengumpulan data yaitu melalui teknik wawancara, observasi, dan dokumentasi. Dan teknik keabsahan data menggunakan triangulasi sumber dan metode. Dan teknik analisis data menggunakan pengumpulan data, reduksi data, penyajian data, dan menarik kesimpulan. Hasil penelitian Bahwasanya langkah-langkah atta'bir almushawwar dengan menggunakan kitab Muthala'ah alqiro'ah al-rosyidah yaitu Guru membacakan kosa kata dengan suara yang keras dan siswa mengikutinya, dan guru meminta siswa untuk mengartikannya, Guru meminta siswa untuk mendengarkan penjelasan guru dengan media gambar dipapan tulis dan dalam keadaan siswa tidak membuka kitab, Guru meminta siswa 
untuk membaca kitab muthalaah dan kemudian memberikan siswa waktu untuk bertanya mengenai kosa kata atau hal yang belum dipahami, Guru meminta beberapa siswa untuk menceritakan kembali apa yang telah dijelaskan oleh guru didepan kelas dengan menggunakan bahasa arab. Dengan menggunakan strategi attakbir almushawwar dalam pembelajaran kitab muthalaah sangat membantu siswa dalam mengingat materi yang telah dijelaskan oleh guru. Karena penjelasan menggunakan media gambar membuat siswa tertarik sehingga siswa memperhatikan skali apa yang dijelaskan oleh guru. Dan ditambah lagi siswa harus menghafalkan kembali dengan menggunakan bahasa arab yang telah mereka pahami, dengan inilah siswa terlatih dalam beribicara dan dapat meningkatkan maharah kalam siswa.

Kata Kunci : Atta'bir Almushawwar, Maharah Kalam, Muthalaah, Al Qiroah Al rasyidah.

اللّغة العربيّة معروفة على الأرض دوليّا عالميّا بعد اللّغة الإسبانيَة, فطبعا لما سهم كبير في الإربحال

و هو الإربحال في القطاع منهجيّة و طريقة التّعليم. هذا الرّأي يستطيع أن يشهد بالكامل و الواقعيّة في التّعليم اللّغة العربيّة, و الآن كثير من الطرّيقة التّعليم اللّني سوف يزيد النّشاط التّلاميذ ليتعلمّ اللّغة العربيّة بالمستدامة.

تحتل اللّغة العربيّة موقّعا إستراتيجيّا بين مختلف اللّغات العالميّة. هذا له تأثير على عاجل اللّغة العربيّة الّتي تتطوّر دائما في أيّ وقت في هذا العصر العالميّ. هناك حاجة ملحة اللّغة العربيّة منها اللّغة العربيّه كلغة القرآن الكريم, لأنّ أنزل القرآن باللّغة العربيّة و يحتاج على كلّ مسلم قراءة القرآن و فهمه، و يبعل القرآن على مؤسّسة لعمل أمر الله و ترك ما فهى الله. واللّغة العبيّة اللّغة في الصّالاة، لأنّ كلّ مسلم يصلّى باللّغة العربيّة. فلذلك اللّغة العربيّة لديها علاقة مع أركان الإسالام. و المزيد من مستخدمي اللّغة العربيّة، في عام ع 9 ا ر أصبح مالا يقلّ عن بr دولة بيجعلها اللّغة الأولى و أصبحت اللّغة الثّانيّة للدّولة الإسلاميّة. (Zulhannan, 2014:1-4)

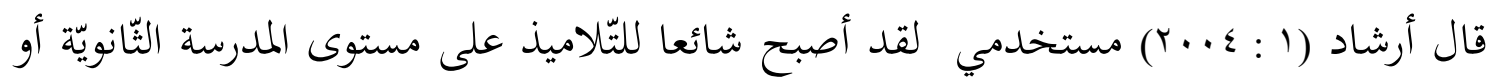
المدرسة العالية, أنّ الدّرس اللّغة العربيّة تدخل في فئة الدّروس الصّّعة.أمّا أنّ كلّ التّلاميذ دين الإسلاميّ يعرف اللّغة العربيّة منذ الصّغر , يمكن بالمباشرة أو غير المباشرة أو بمعنى الآخر بين اللّغات الأجنبيّة أقرب إلى حيات التّلاميذ يعني اللّغة العربيّة.

رأى شيف المصطفى (107: 11 (1) أنّ التّعليم اللّغة العربيّة خاصّة في مهارة الكاملام, وجد المدرّس

أفّم يلوموا التّلاميذ عند محارسة اللّغة العربيّة لفظيّا. بدليل: الخطأ في القواعد أو الخطأ في النّطق و غير 
ذلك. إمّا في أيّ إستراتيجيّة لتّعليم اللّغة خاصّة في مهارة الكلام, المدرّس أن لا يلوم أو يصحّح ممارسة اللّغة للتّلاميذ. يتمّ ذلك بحيث ينموا التّلاميذ بثقّة الكامل. عامل آخر مهمّ في إحياء مهارة الكلام هو شجاعة التّلاميذ و الشّعور بعدم الخوف من الخططإ. لذالك يجب على المدرّس أن يكون قادرا على إعطاء التّشجيع للتّلاميذ ليجرؤوا على الكلام حتّى لوكانوا مخطئن. و عليها التّأكيد على أنّ الخوف من الخوف هو أكبر. (musthofa, 2012:136)

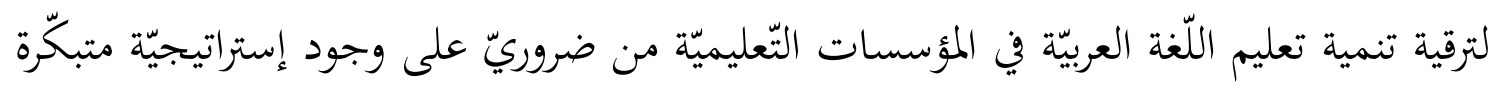

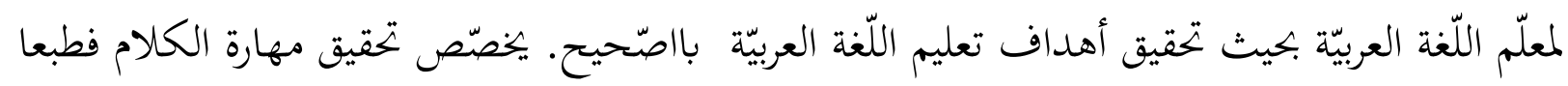

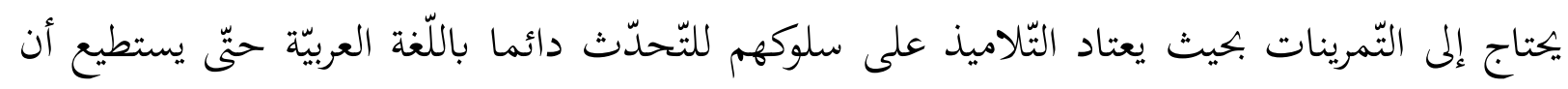

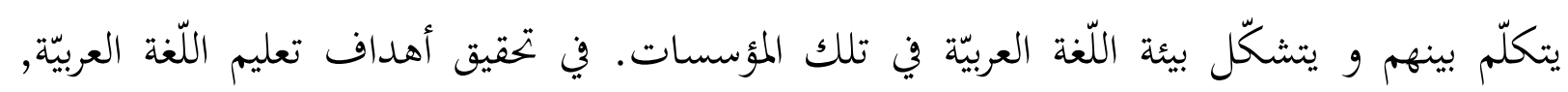

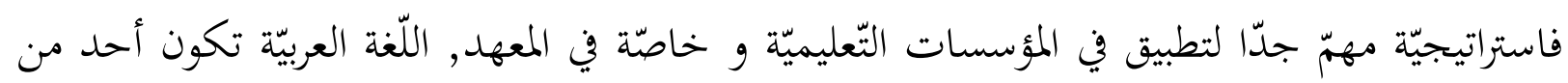

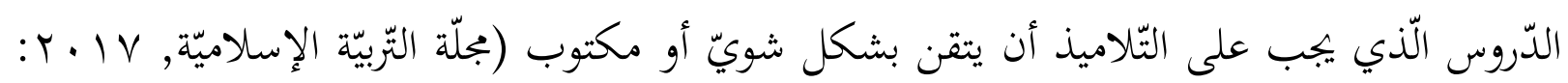

ستكون أنشطة التّعليم و التّعلّم إذا كانت في العمليّة مصحوبة باستخدام الوسائل كالآلة للتّعليم. قال عارف ساديمان و غيره عن تعريف الوسائل و هي كلّ ما يمكن إستخدامه لتسليم الرّسائل من المرسل إلى المستلم. بحيث يمكن أن يحفز عقل التّلاميذ و مشاعرهم و اهتمامهم في عمليّة التّعليم و التّعلم. (musthofa, 2012:29) أهمّية الوسائل التّعليميّة في أفّّا تساعد على إستثارة المتعلّمين و إشباع حاجتهم. وكذلك تعمل

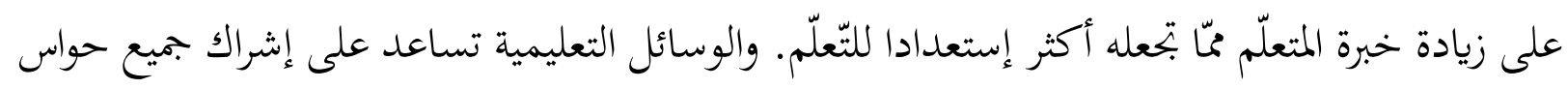

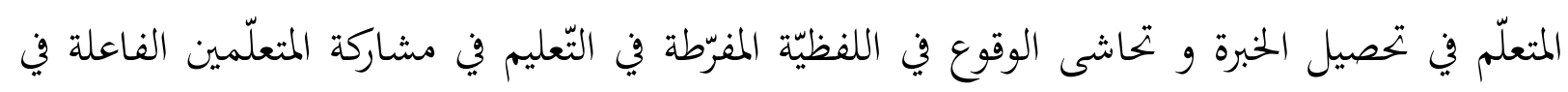

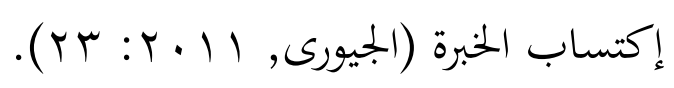

كانت النّريّة القديمة للتّعليم تركز على تكثيف المعلومات النّظريّة و تلقينها للمتعلّم عن طريق التّحفيظ و التّسميع, و كان المدرّس هو المصدر الأوّل للمعرفة و العامل الفعّال في عمليّة التّعليم. أمّا

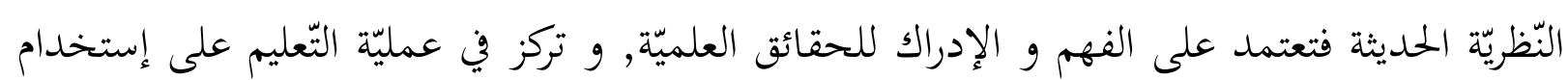

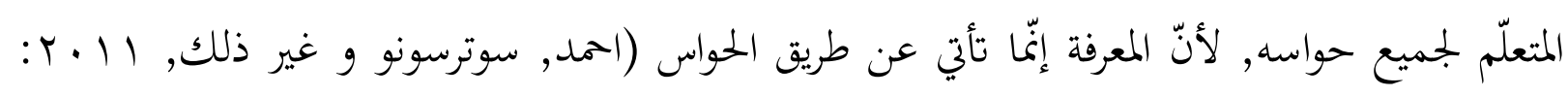


ينبغي أن تعتمد الطّريقة التّي يدرس بها المعلّم على بعض الأسس العامّة الّتي بتعل منعا طريقة

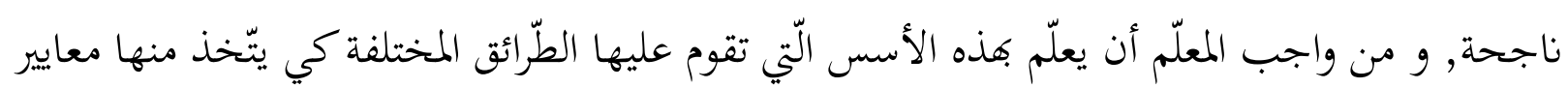

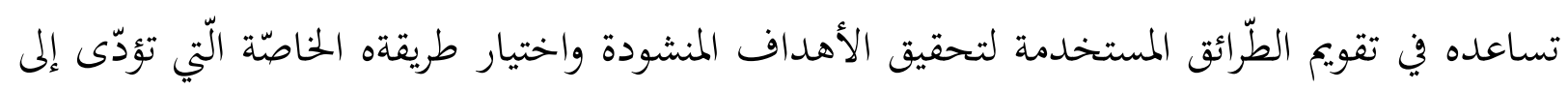

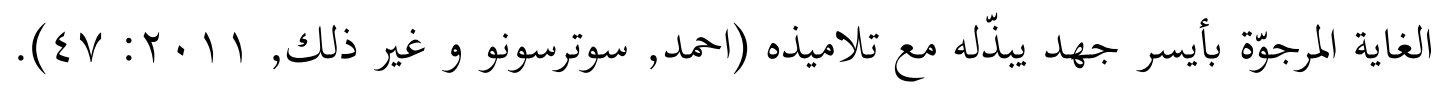

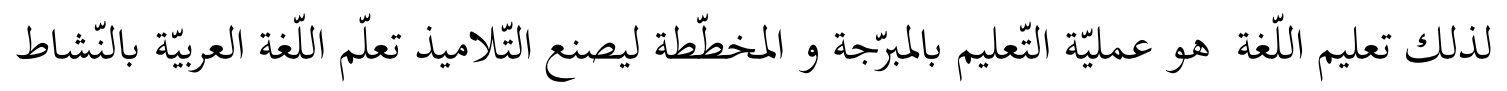

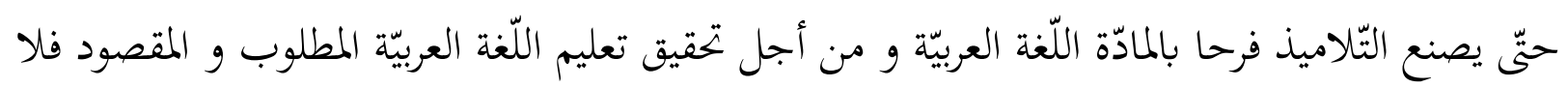

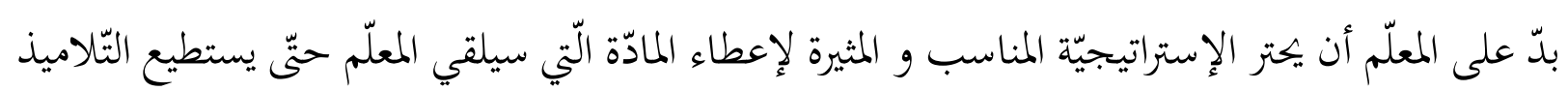

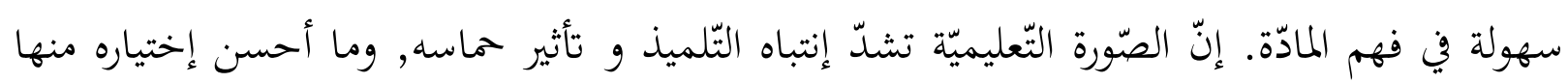
يساعد التّلميذ على فهم و استيعاب و تذكّر المعلومات المتضمّنة في المواظ اللّظظيّة, و كما قال المثال

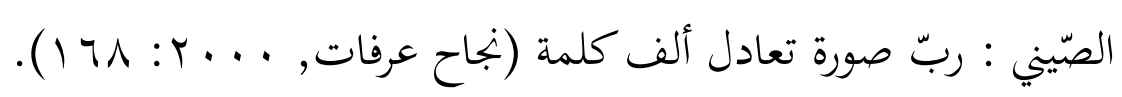

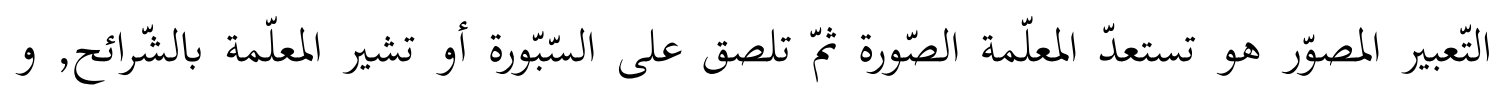

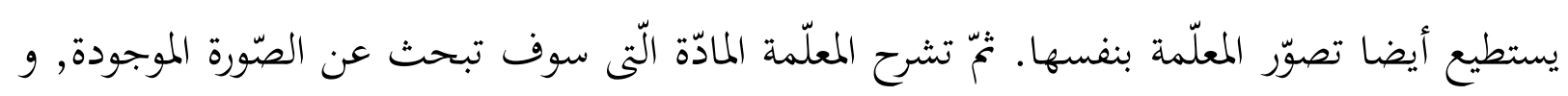

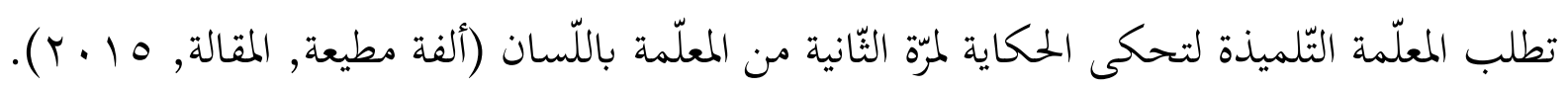

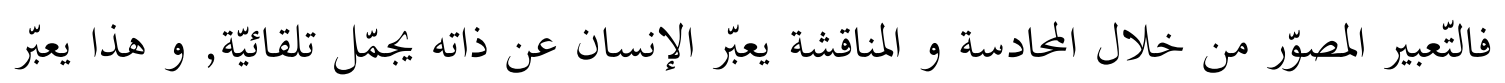

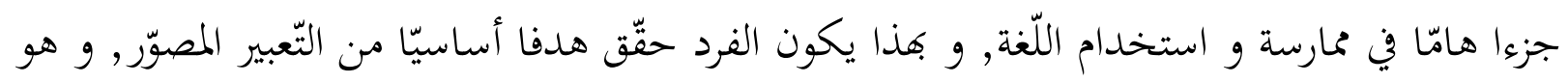

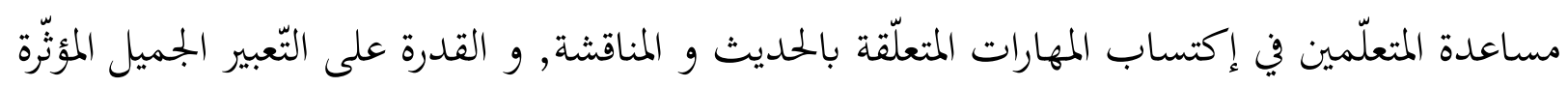

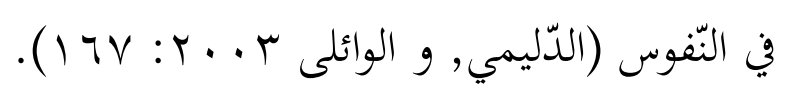
معهد تعمير الإسلام هو تطبيق المعهد النّام "يجب على جميع التّلاميذ إستخدام اللّغة العربيّة في

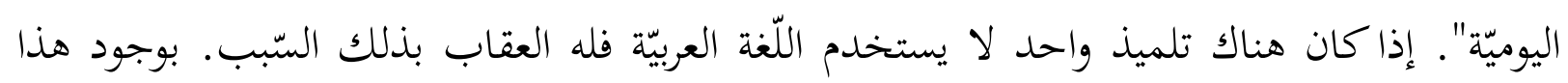

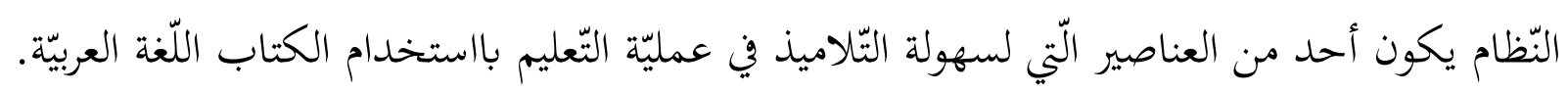
بوجود الإستراتيجيّة الكثيرة, أخذت الباحثة أحد من الإستراتيجيّة هي إستراتيجيّة التعبير المصوّر.

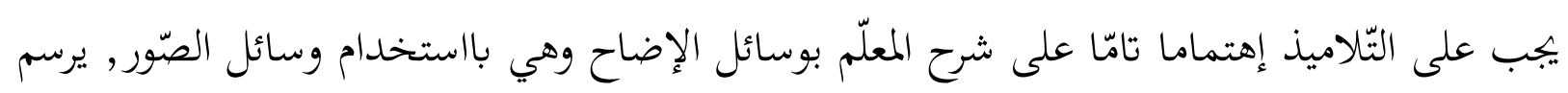

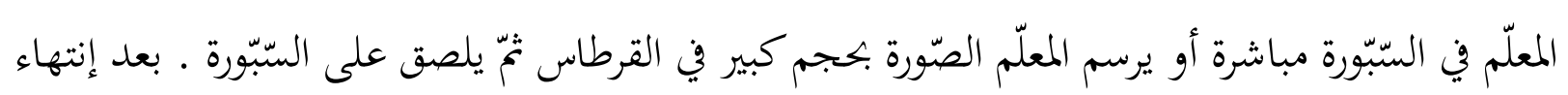
الشّرح من المعلّم, يجب على جميع التّلاميذ ليشرح بما يفهم التّلاميذ. 
إحتارت الباحثة الإستراتيجيّة التعبير المصوّر في تعليم المطالعة على كتاب "القراءة الرّشيدة", لأنّه وفقا للباحثة "أنّ كتاب القراءة الرّشيدة في مدرسة الأخرى عادة يستخدم مهارة القراءة أو مهارة الكتابة". ولكنّ في المعهد تعمير الإسلام يستخدم إستراتيجيّة التعبير المصوّر بمهارة الكلام, وبهذا وفقا للباحثة هناك جانب التّعليم الأخرى بين مدرسة الأخرى في تعليم كتاب المطالعة "القراءة الرّشيدة".

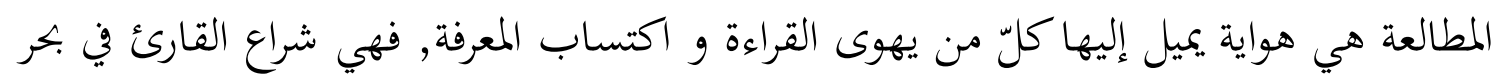

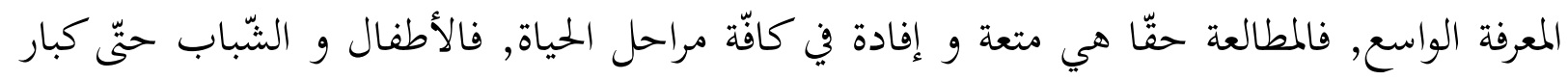

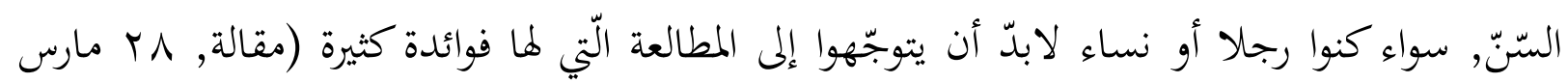
.$(r \cdot 19$

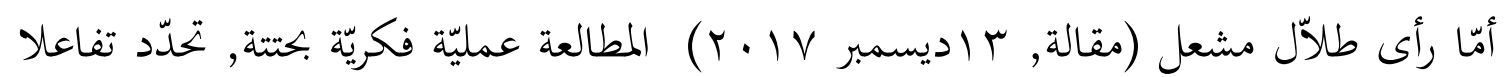

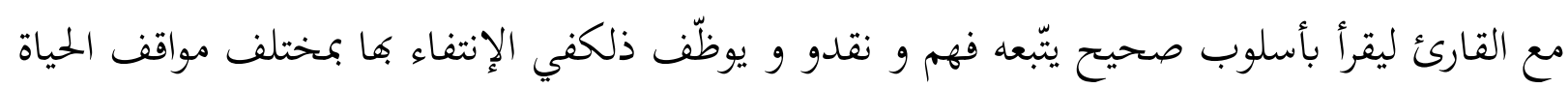
و مواجهة المشاكل و حلّها. يستند على نتائج المقابلات الّتي عملت الباحثة في المعهد تعمير الإسلام للفصل الثّاني في يوم

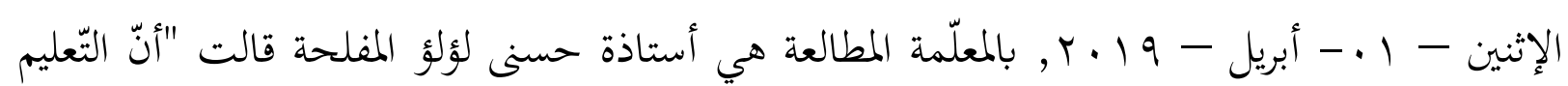

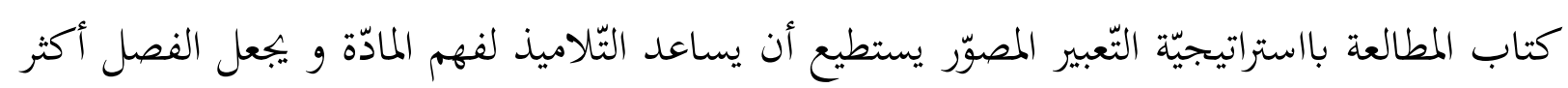

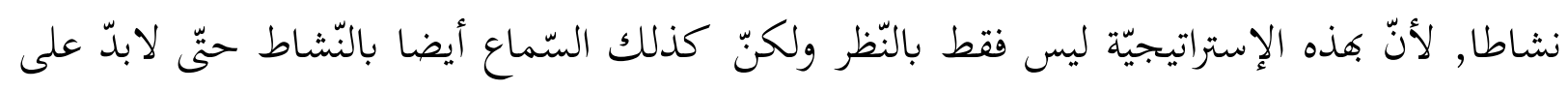

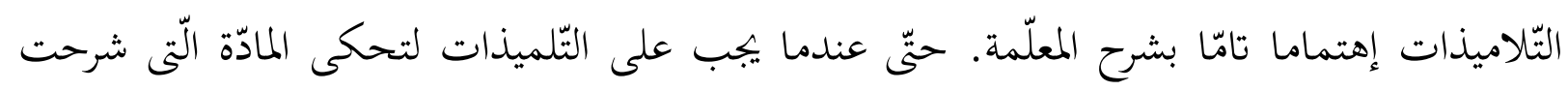

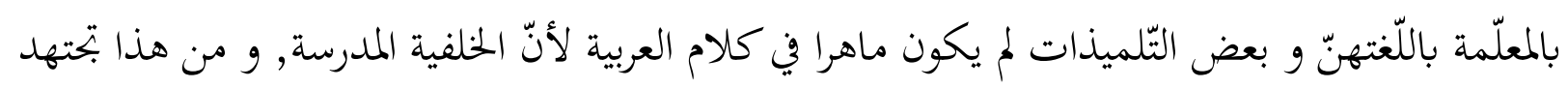
المعلّمة في مساعدة التّلميذات لسهولة على فهم المادّة يعني باستخدام إستراتيجيّة التّعبير المصوّر.

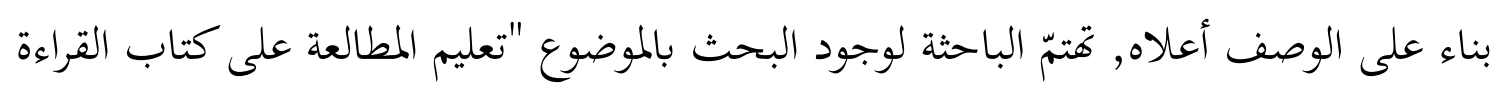

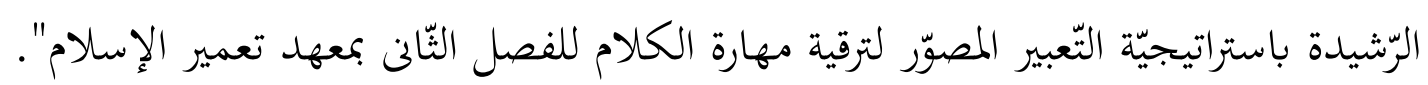

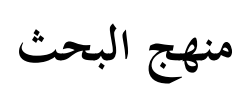
يستخدم هذا البحث طريقة البحث الوصفي. هذا البحث ينفذ من شهر يونيو 9 . ب حتى شهر أغستس 9 ا • ب. و. و في هذا البحث، تأخذ الباحثة مكان البحث بمعهد تعمير الإسلام سوراكرتا.

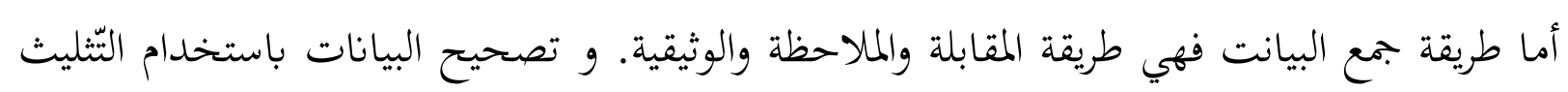

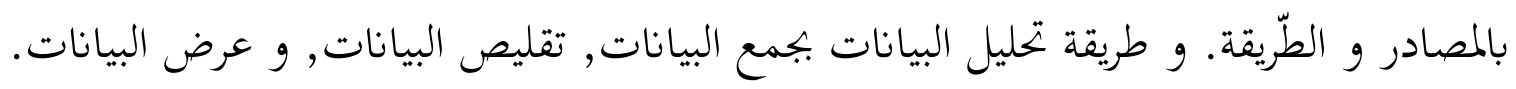




\section{نتائج البحث}

\section{إستراتيجيّة التّعبير المصوّر}

التّبير هو إبانة و إفصاح عمّا يحول في النّفس من خواطر و أفكار , و تطبيق لمفاهم, و حقائق

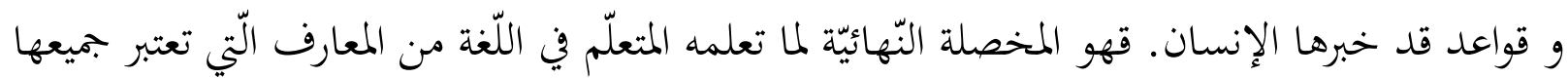

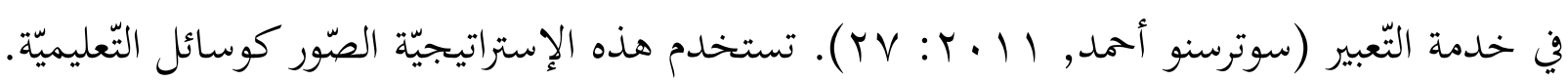

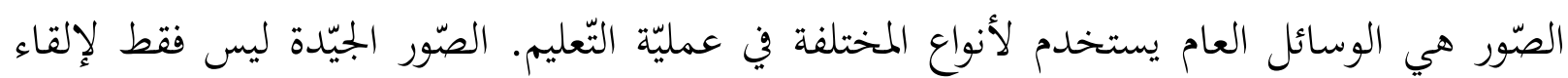
عمليّة التّعليم, ولكنّ يستطيع أن يستعمل لممارسة مهارة التّكير و يستطيع أن يتطوّر مهارة خيال

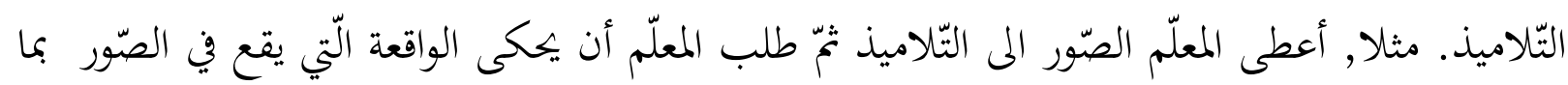

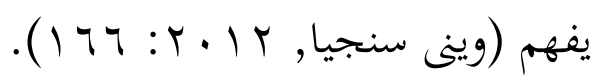

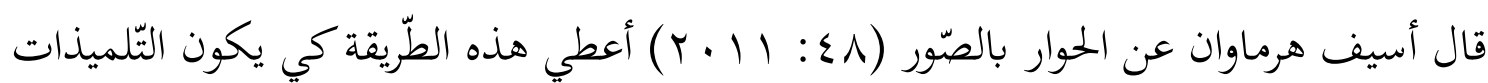

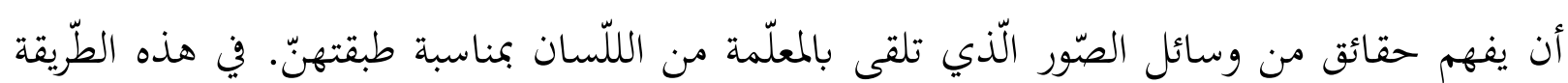

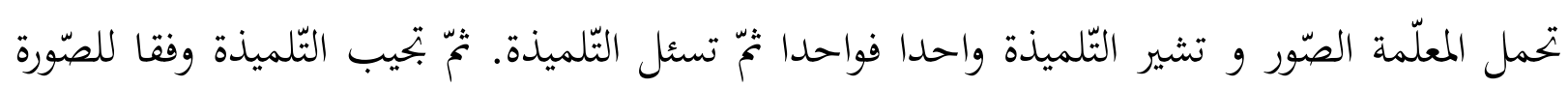
الموضّحة.

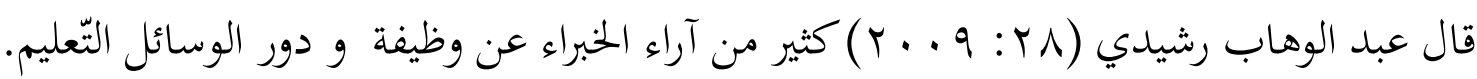

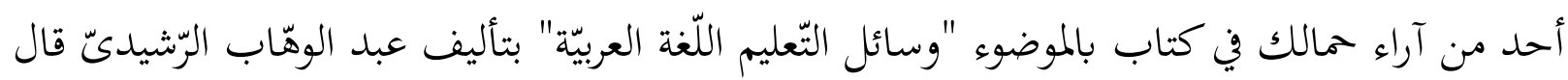

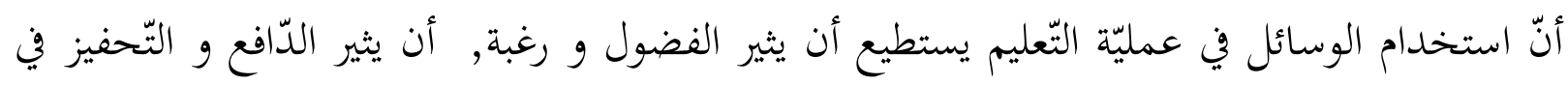

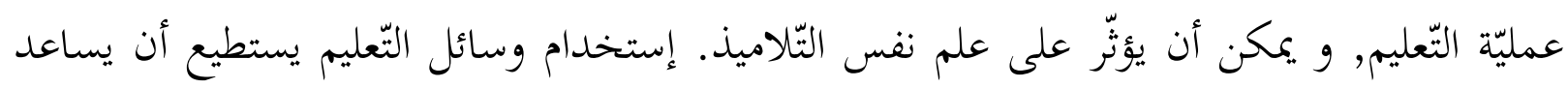

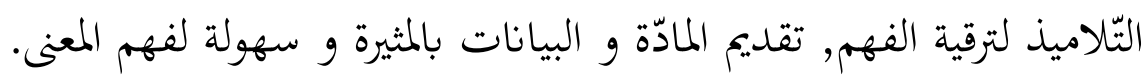

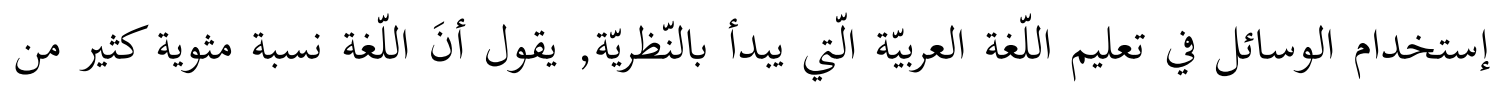

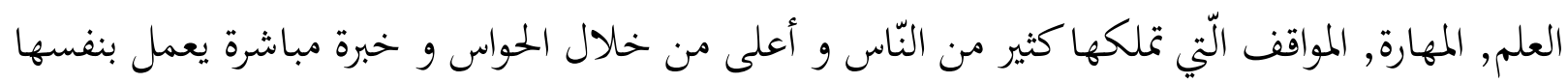

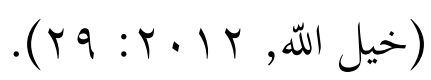

في تعليم مهارة الكلام, يمكن إستخدام وسائل الصّور كالموضوع في الكالام. عادة في التّعليم

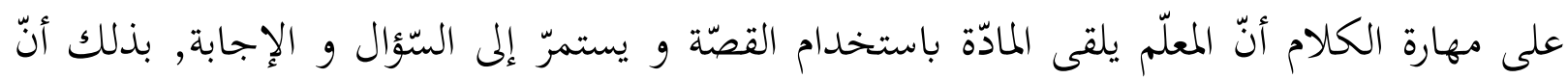

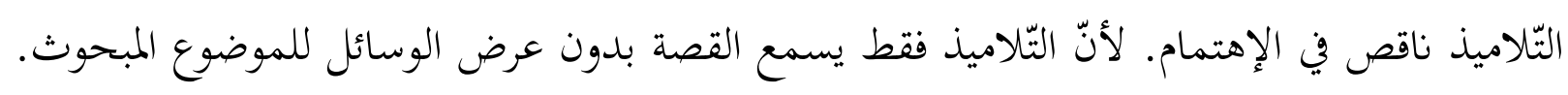


هذه الوسائل الصّورة إذا يخلّط بالقصّة, و السّؤال و الإجابة في إلقاء المادّة على تعليم مهارة الكلام,

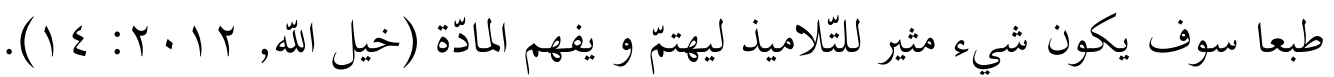

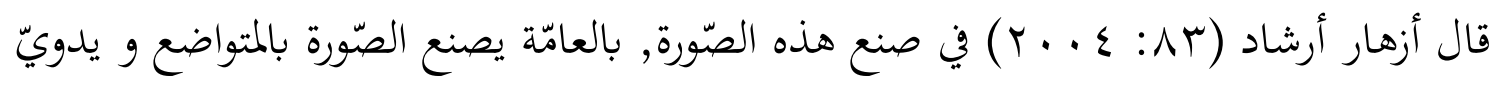

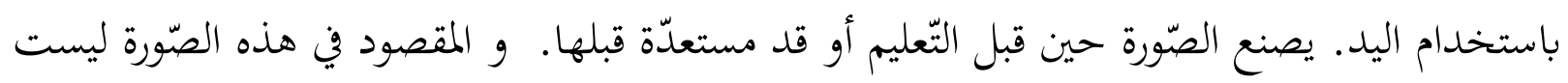
صورة جميلة الّتى يصنع بها صانع الصّورة, و لكنّ صانع الصّورة يعنى المعلّم اللّغة العربيّة.

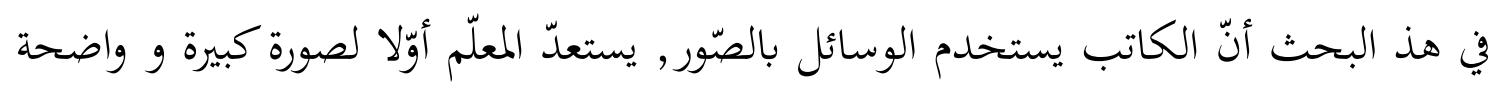
ليراها التّلاميذ بسهولة. أو يشرح المعلّم بالصّور الكبيرة على السّبّورة.

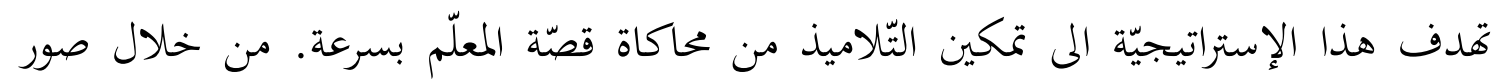

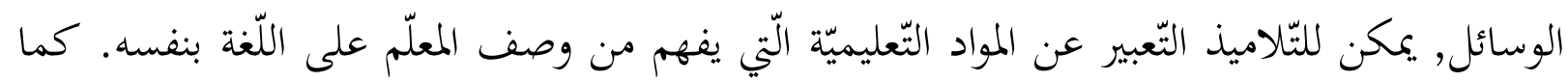

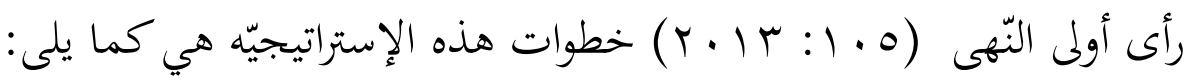

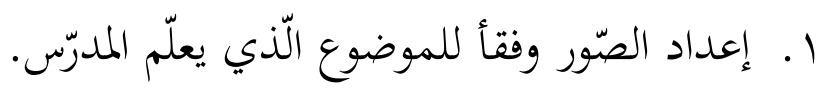

$$
\begin{aligned}
& \text { r. التّصق الصّورة على السّبّورة. }
\end{aligned}
$$

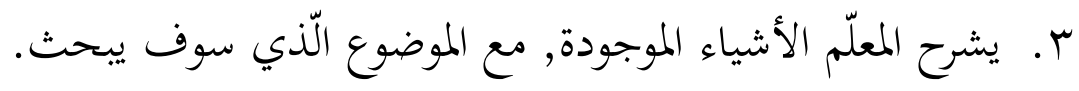

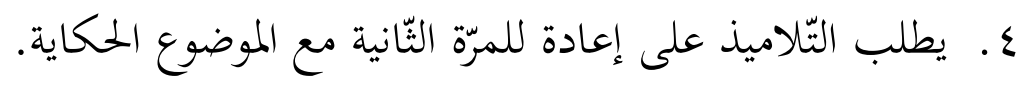

مهارة الكلام

لأسيب هيرماوان, أنّ مهارة الكلام هي القدرة على التّعبير عن الأصوات أو الكلمات للتّعبير

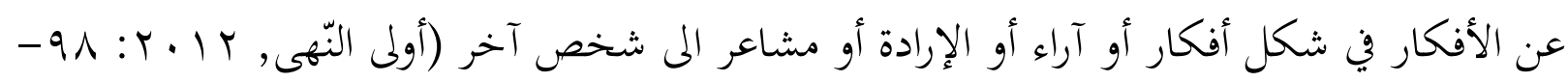

أمّا رأى هنرى غتتور تريغان (10 1: ع99 1 ) مهارة الكلام هي القدرة على التّعبير عن أصوات

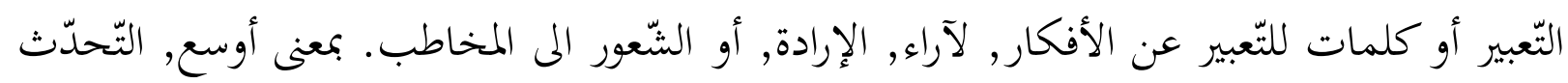

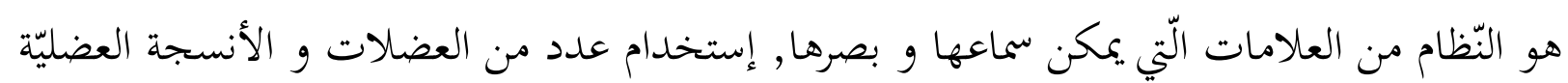
لإلقاء الفكرة لتلبية إحتياجم.

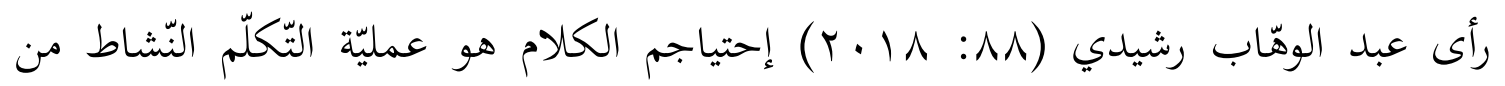

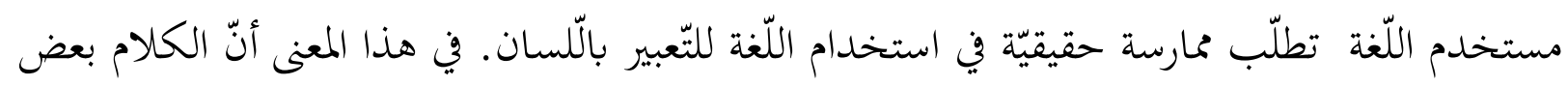


من مهارات اللّغة النّشاط و الإنتاجيّة, تطلّب مهارة الكلام في الإتقان لبعض الجوانب و القواعد لإستخدام اللّغة.

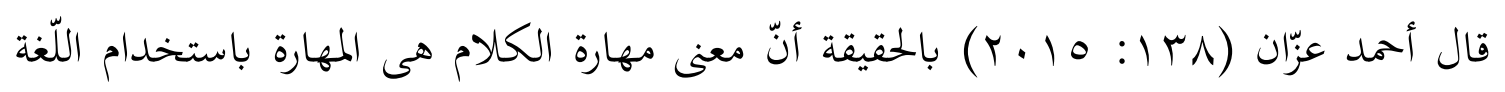

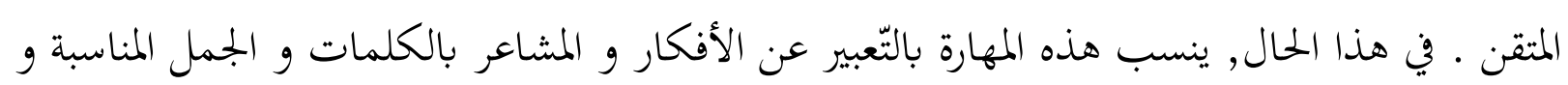

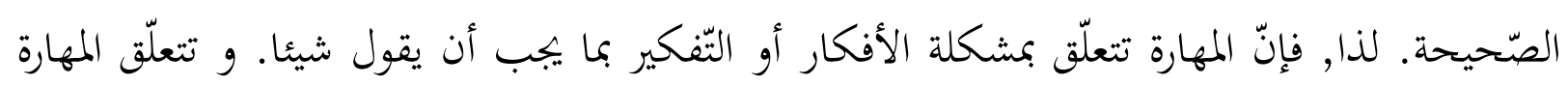

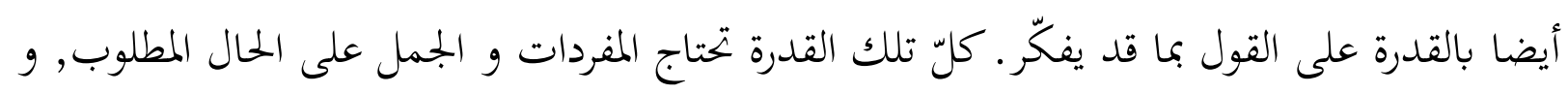

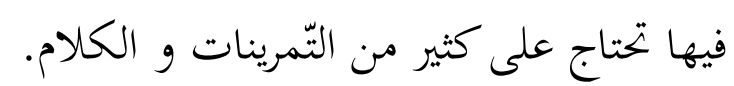

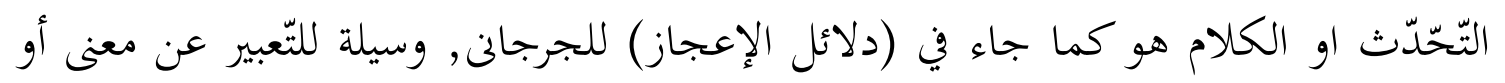

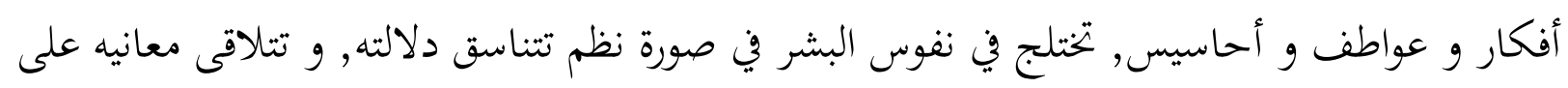

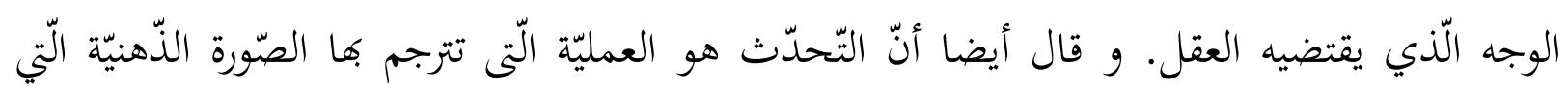

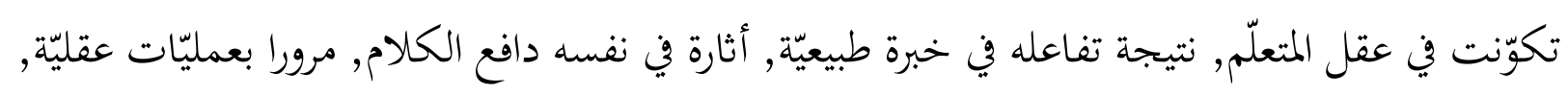

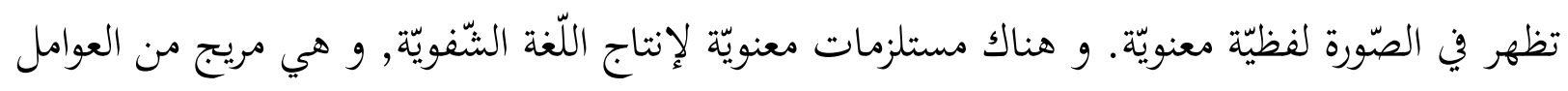

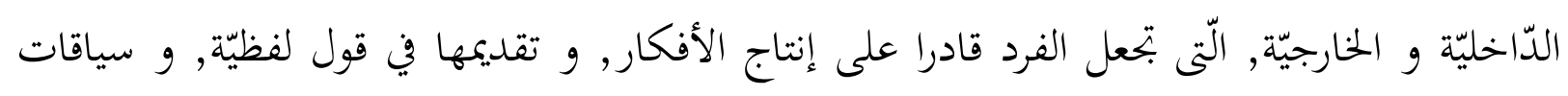

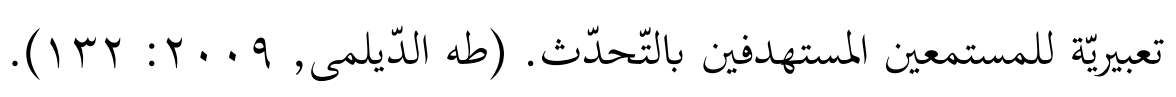

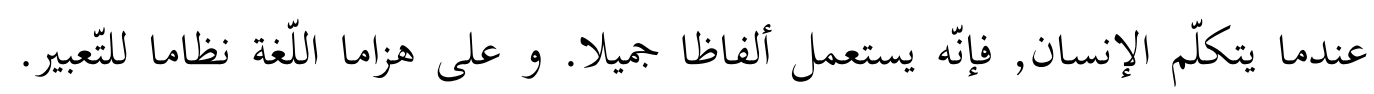
فالإنسان للعادى يعبّر عن أفكاره و مشاكله باللّغة, و اللّغة أيضا نظام للتّجارب الثّبعوريّة النّنسيّة التّي

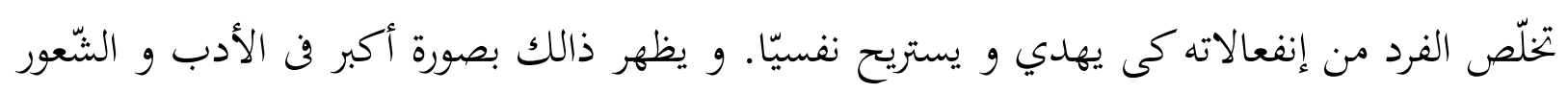

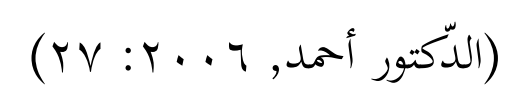
مهارة الكلام هى مهارة مهمّة في التّكلّم. لأنّ الكلام هو بعض من مهارة التّي قد درس التّاميذ, حتّى أفترض مهارة الكالام كبعض أساسيّ في التّعليم اللّغة الأجنبيّ.

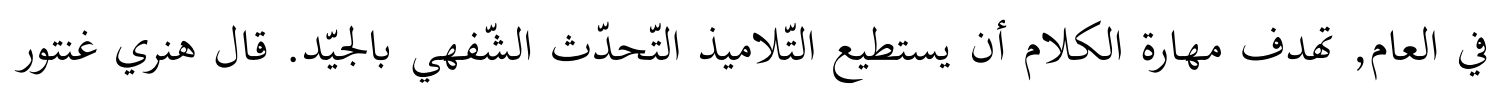
تاريغان, الهدف الأوّل هو للّّحدّث. كي يستطيع أن يلقي الفكرة المؤثّر فلابدّ على المّلى المتكلّم أن يفهم

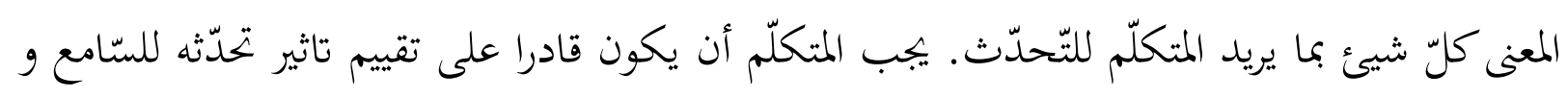

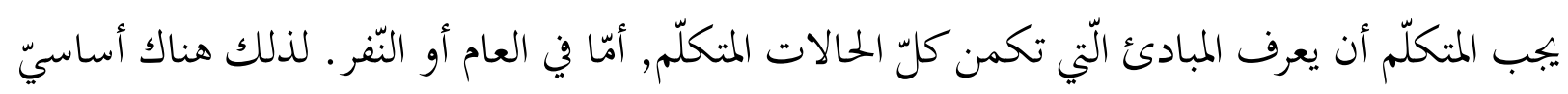


التّحدّث لغرض العام كما يلي: إخطار, إبلاغ, ترفية, إقناع, دعوة, و مقنع (هنرى غتتور تريغان, .$(10: 1995$

الغرض من تعليم مهارة الكلام: أوّلا, سهولة الكلام يجب على التّلاميذ أن يوجد فرصة كبيرة لممارسة الكلام حتّى يستطيعوا من تطوير مهارة الكلام بالمرتاح, و يسرّ في مجموعات صغئ صغيرة وأمام

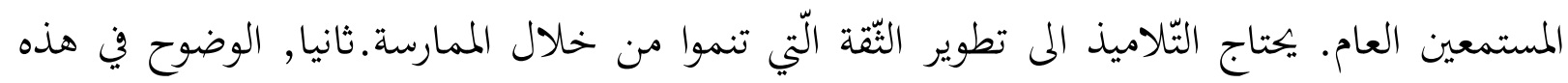

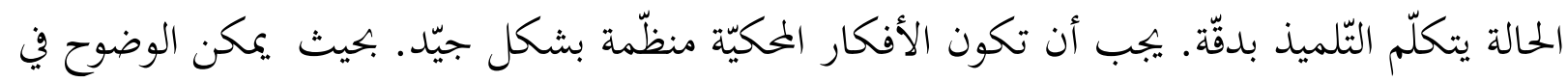
الكلام بشكل صحيح. ثالثا, مسؤول, ممارسة الكلام و يشدّد على المحادسة ليكون مسؤولا لكي يتكلّم

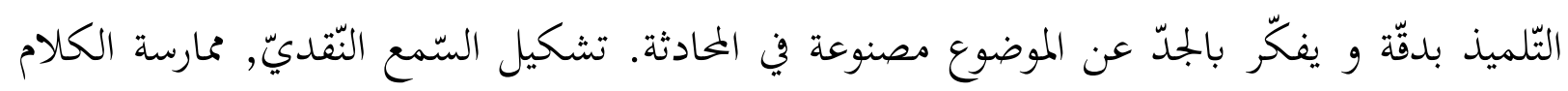

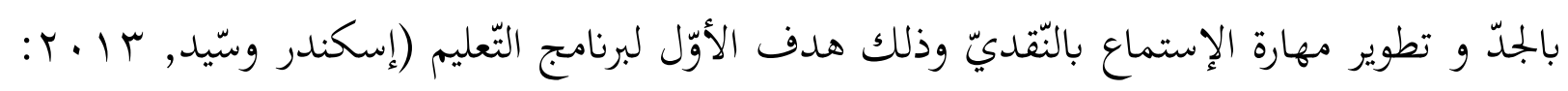

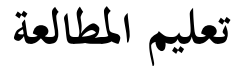

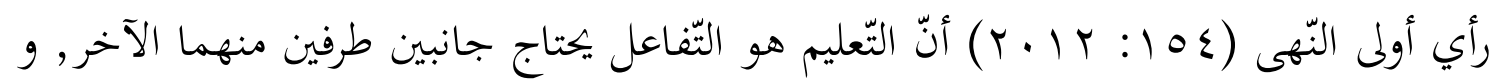

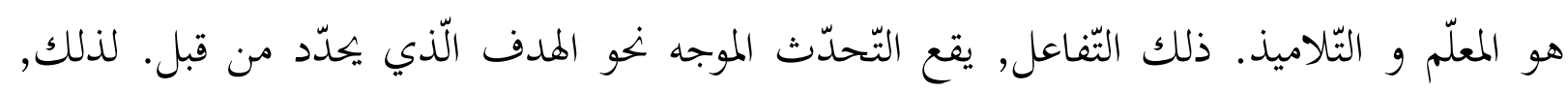

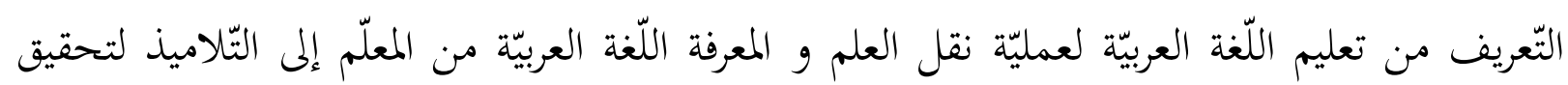

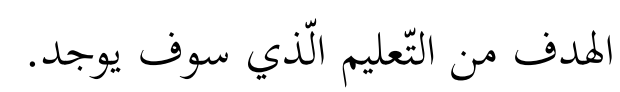

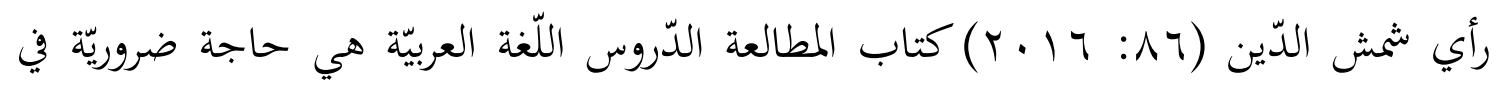
عمليّة التّعليم اللّغة العربيّة, لأنّ المطالعة الجيّدة تعني أحد من العوامل لا يمكن بتحاهلها في تحقيق النّجاح

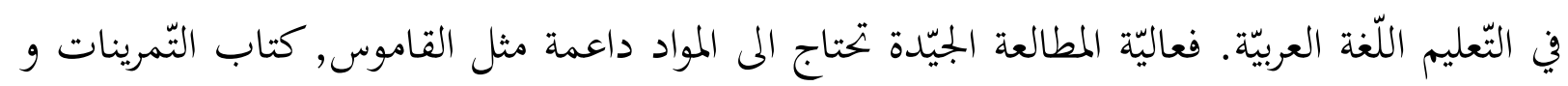
غير ذلك.

أنّ محتويات القراءة كى يكون قراءة متتعة, يجب أن تكون في شكل قصص قصيرة, تاريح قصير,

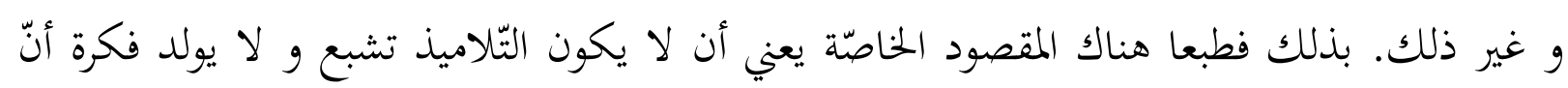

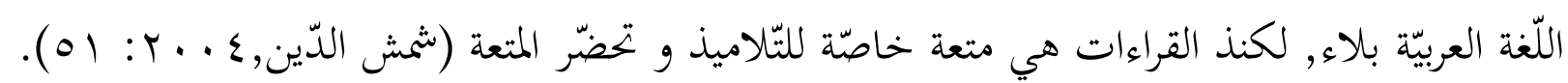

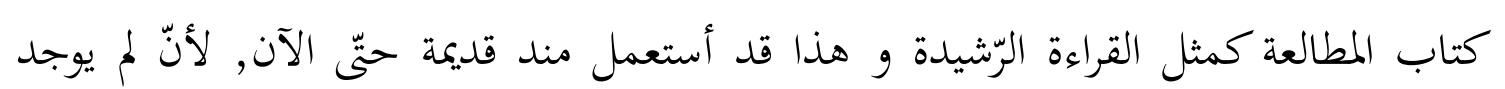

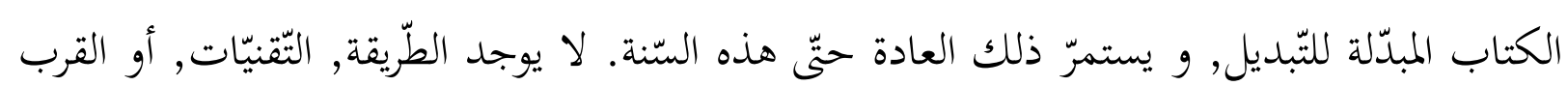

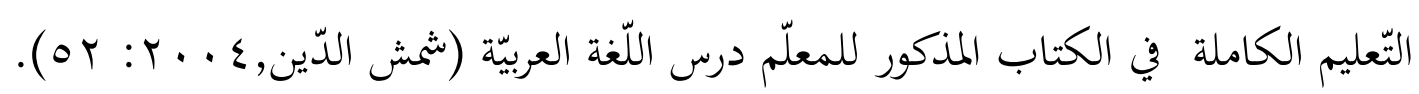


هناك شيء واحد مهمّ جانب نوعى التّدريب وهو التّدريب لترجمة المطالعة. في تعليم اللّغة العربيّة,

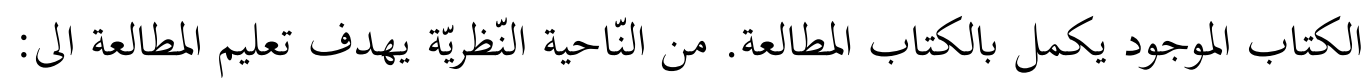

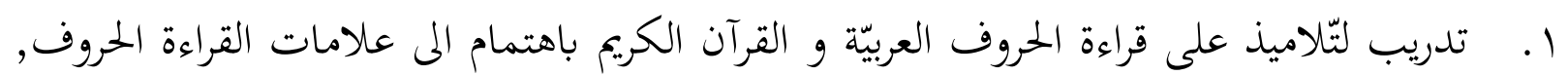
مثل: الفتحة, الضّمّة, الكسرة, و غير ذلك. r. يستطيع أن يفرّق بين حرف وا حد الى حرف الأخرى, و بين العربيّة الخفيّة , حتّى يكون فاصحا.

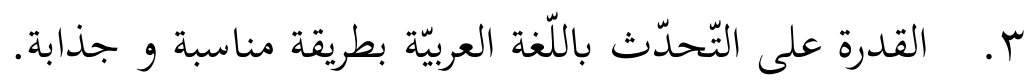

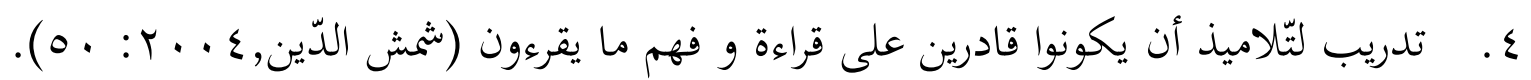

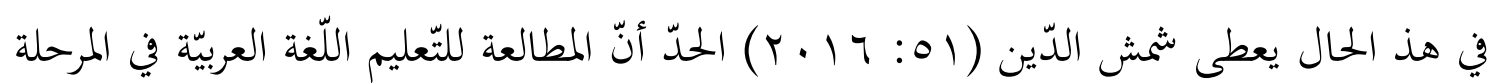
الأولى كافيا ليتطلّب المفردات حول . . ب كلمات, وذلك مأخوذة من الكلمات الّتي إستخدامها عالية

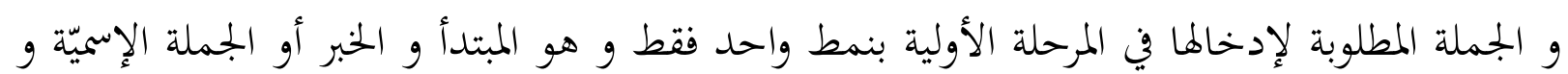

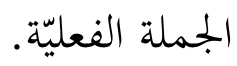

أنّ الغرض من درس المطالعة هو تعويد التّلاميذ فهم ما يقرؤون من الكتب و غيرها فهما جيّدا سريعا من غير كدّ أو مشقّة, ثنّ جودة النّطق و حسن الإلقاء حتّى يسهل على نعلى السّامع أيضا فهم الآراء و المعاني التّي يراد توصيلها إليه.

فتحقيقا لتلك الأهداف, لا بدّ أن تتوافر في المطالعة الشّروط الآتية:

$$
\text { ا ـ. إخراج لحروف من مخارجا الصّحيحة }
$$

r. نطق الكلمات و العبارات القائمة بنفسها دفعة واحدة و فصلها عن غيرها حسب المعنى من من غير

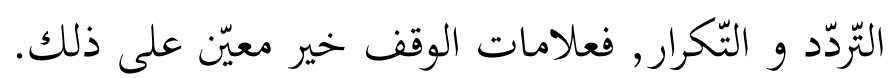

r. تنويع الصّوت بين رفع و خفض, و شدّة و ليّن, بحسب المناسبات, بشرط أن يظهر القارئ ما

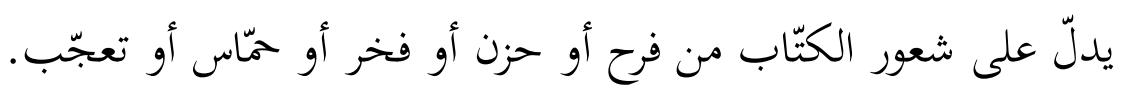

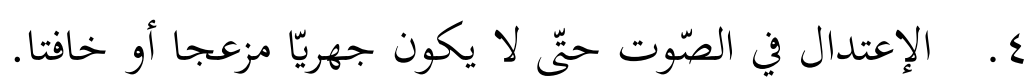

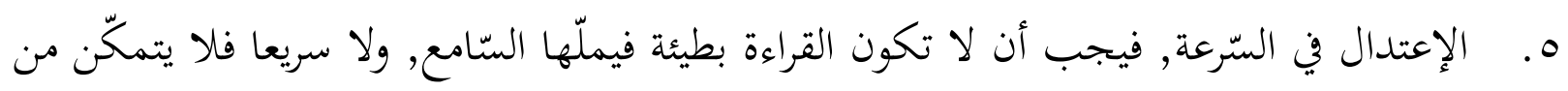
إحسان فهمها.

ج. ملاحظة المدّ, و الإدغام, و القلب, و الإخفاء, و الوقف, و غيرها (سوترسنو أحمد, 11. ب: . $\left(r \varepsilon-r_{0}\right.$ 
رأى محمّد طيّب على المقالة المؤتمر الدّولى اللّغة العربيّة و أدها (نور حزب اللّ, 9 ( ـ ؟) أنّ هدف

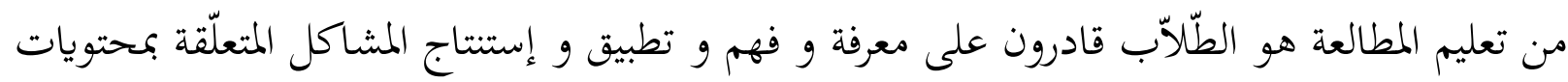

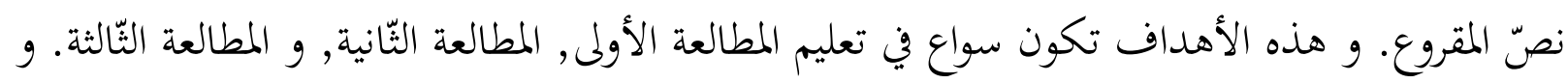

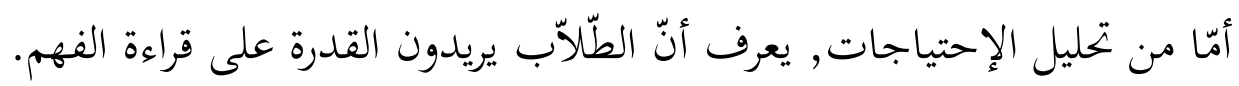
في صياغة الأهداف تعليم المطالعة, فمن الأفضل صياغة الأهداف بشكل أكثر تحديدا بحريث

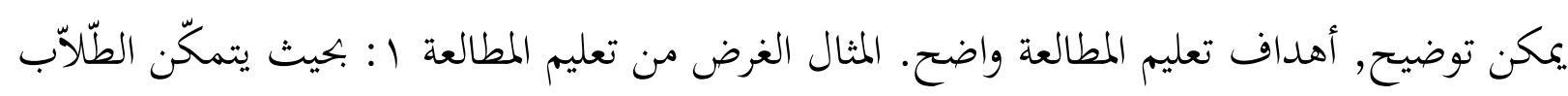

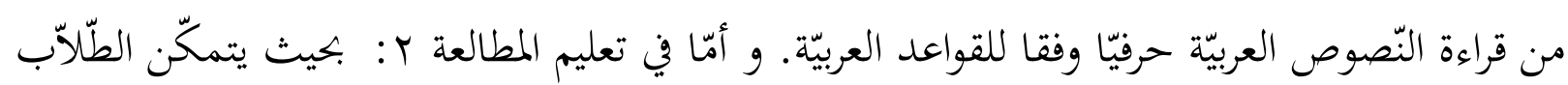

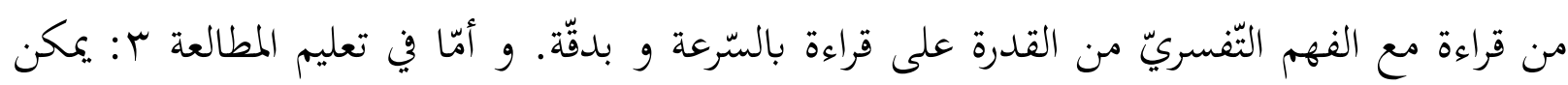

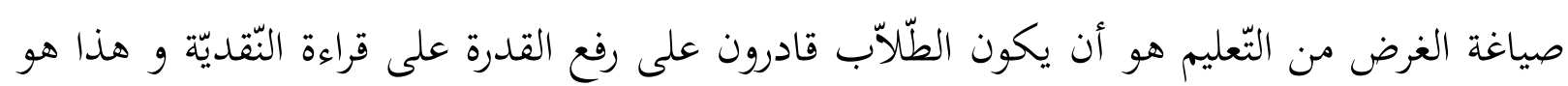
القدرة على المفهوم أو فكرة النّص. و مع ذلك, لا يمكن كتاب المطالعة للتّلاميذ معادلا لكتاب المطالعة للتّلاميذ أجنبيّ, للأنّ هناك

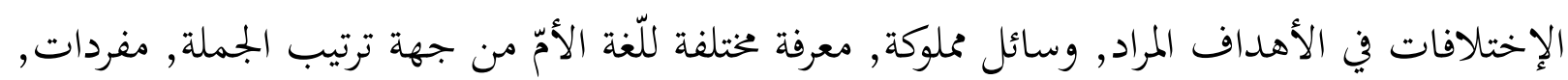

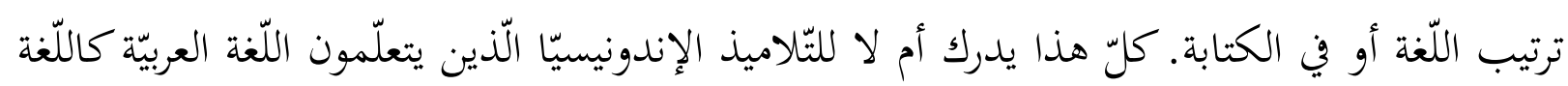
الثّانية سوف يلحق نقل اللّغة الخاطئة. مسألة الأخرى هي أنّ مالك اللّغة نفسها نقصان الإهتمام بذلك في تنمية لغته. على سبيل

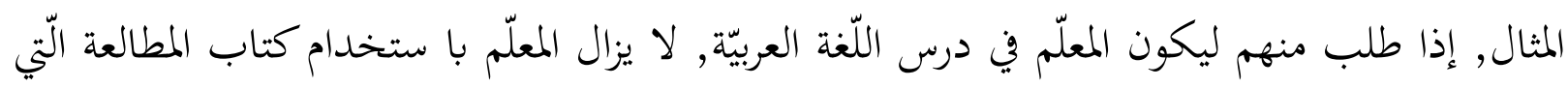

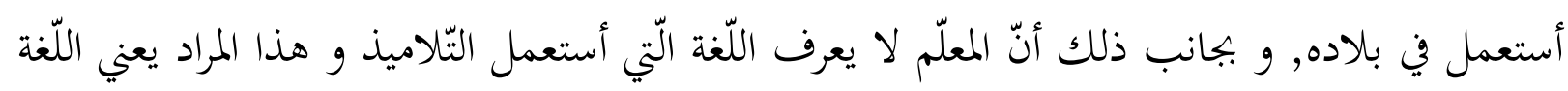
الإندونيسيّا. مسألة كتاب المطالعة ليس شئه غريب, لأنّ نقصان كتاب المطالعة الجيّدة ليس فقط في

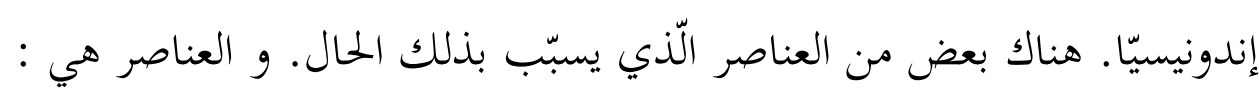
ا ـ نقصان جودة الموارد البشريّة اللّغة العربيّة قليل من الأناس الّذين يفقّه علم اللّغة الحديثة, خاصّة في اللّغة العربيّة من نظام تعليمها للنّاس غير العرب.

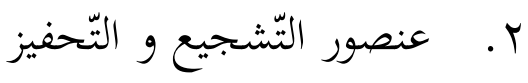


عليّ القاسيميّ يقول أنّ هذا الحال يسبّب قلّة التّشجيع و التّحفيز سواء من حلال المؤسّسات

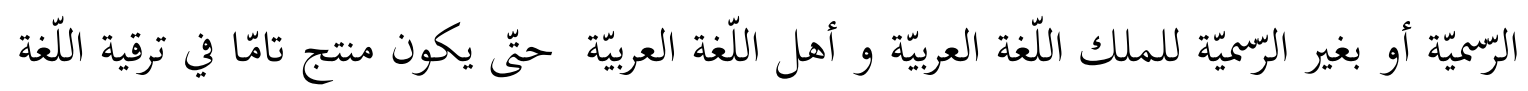

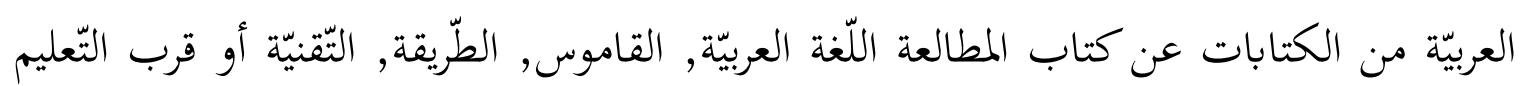

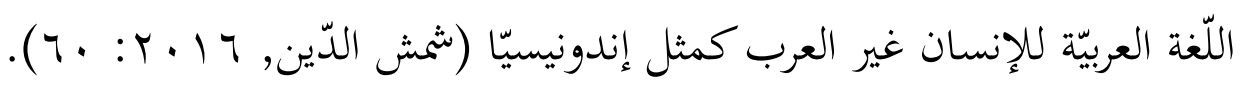

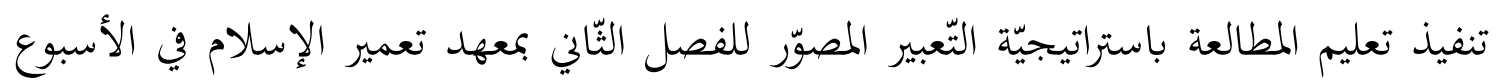

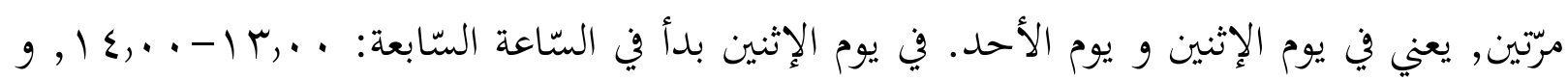

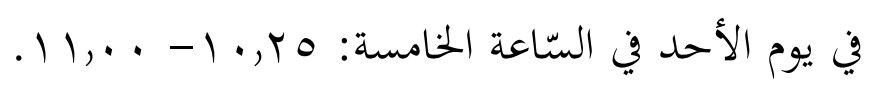

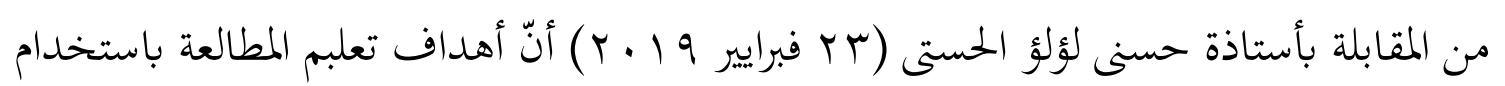
إستراتيجيّة التّعبير المصوّريعنى لتسهيل التّلاميذات في فهم الشّرح من المعلّم و بإستراتيجيّة التّعبير المصوّر

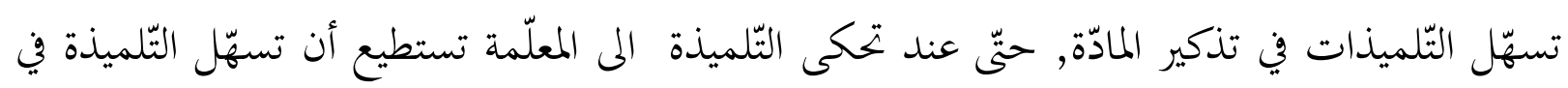

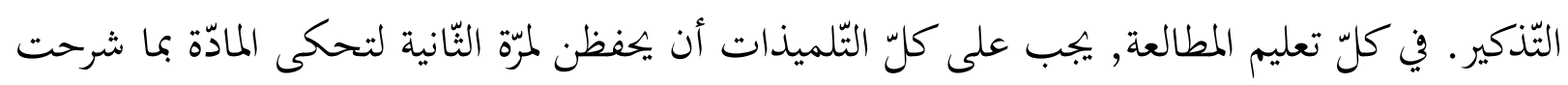
المعلّمة باللّغة العربيّة بما فهمت التّميذة, فبهذا يستطيع أن ترتقى مهارة الكلام التّميذة.

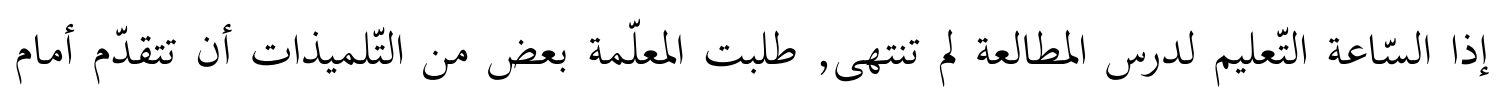
الفصل لشرح المادّة بما تفهم من شرح المعلّمة. بهذا, تستطيع التّلميذة أن تتمرّن في الكلام مع الآخر باستخدام اللّغة اليوميّة لسهولة على الفهم.

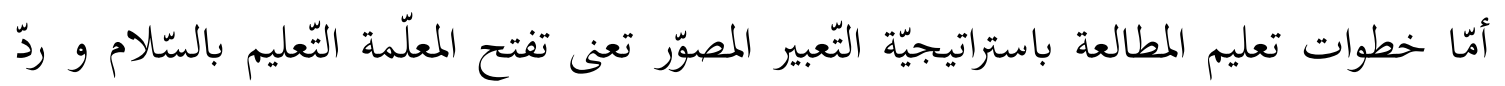

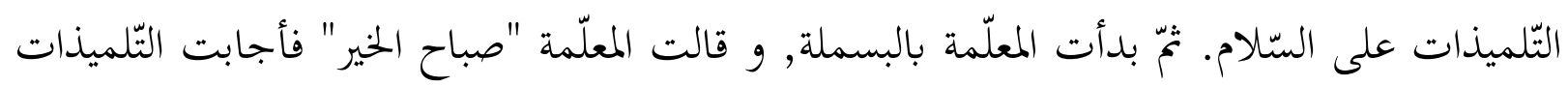

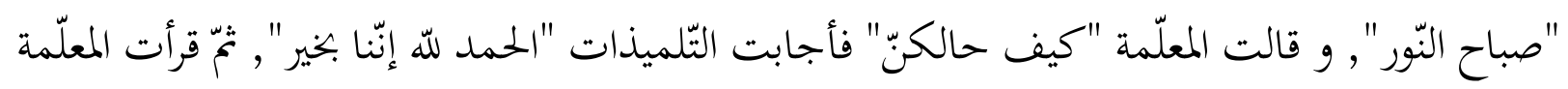
كشف الحضور.

قبل إدخال موضوع جديد, تعطى المعلّمة سؤالا الى التّميذة عن المادّة الماضية. هناك بعض التّلميذات لا يستطعن لإجابة الأسئلة, و بعض التّلميذ التّلمبذات يستطعن لإجابة الأسئلة. بعد إنتهاء

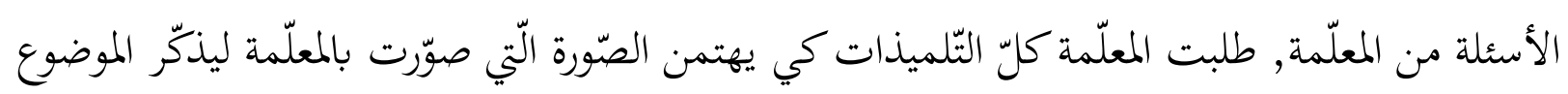

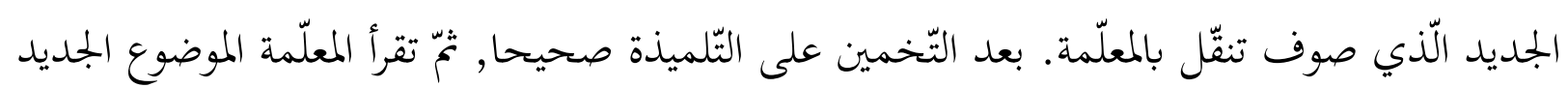
بصوت عال, ثمّ طلبت المعلّمة المى التّلميذات ليقلّدها. 
أعطت المعلّمة المفردات الصّعبة التّي لم يفهمن, يعنى تقرأ المعلّمة المفردة بصوت عال و التّميذات

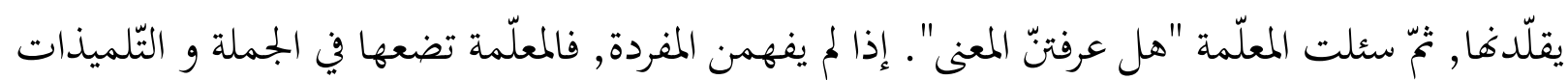

$$
\text { تخمن المعنى من المفردة. و المعلّمة لا يخبر المعنى في الإندونيسيّا. }
$$

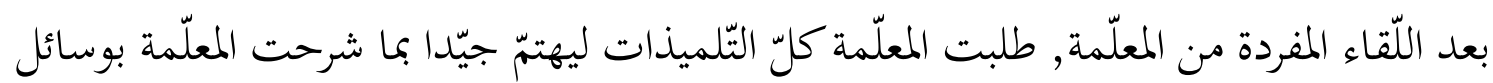
التّليميّة تعنى بالسّورة على السّبّورة. ثمّ شرحت المعلّمة المادّة الجديدة باللّغة العربيّة و المعلّمة تحكى المعلى المادّة

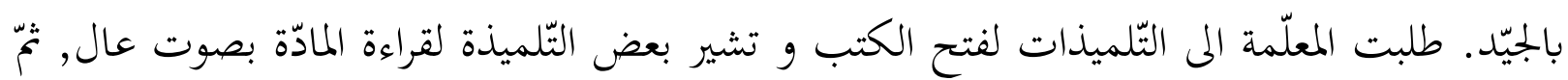

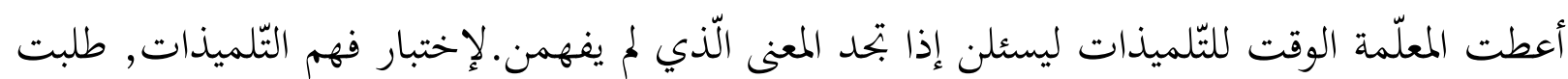

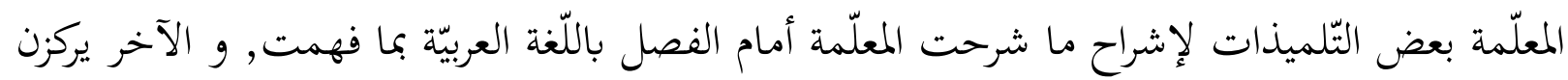

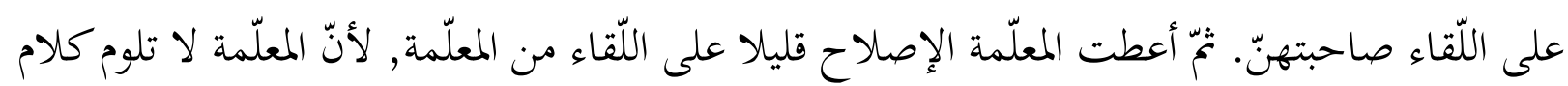

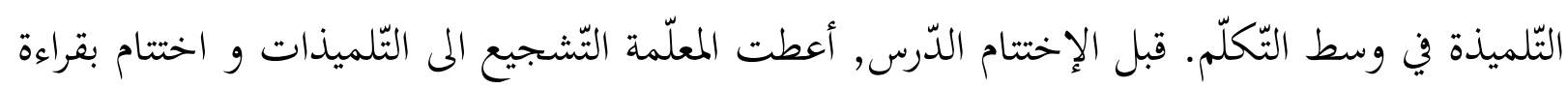
الحمدلة جماعة ثمّ السّلام.

تنفيذ إستراتيجيّة التّبير المصوّر في تعليم المطالعة القراءة الرّشيدة تستطيع أن تسهّل التّلميذات في فهم المادّة التّي شرحت بالمعلّمة و كذلك تستطيع أن تسهّل التّلميذات في التّذكير المادّة عند التّكلّم. ليس فقط ذلك, و لكنّ تستطيع أن تصنع التّميذات النّشاط في إتّباع تعليم المطالعة, و و إذا هناك من بن تنام عند الدّرس, فالمعلّمة تبادر بالسّرعة تعنى أعطت المعلّمة سؤالا اليها.

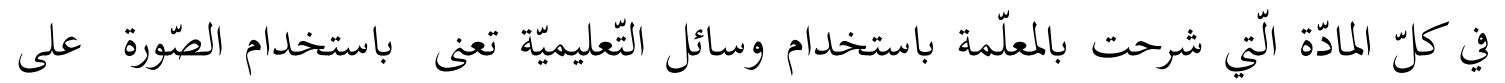

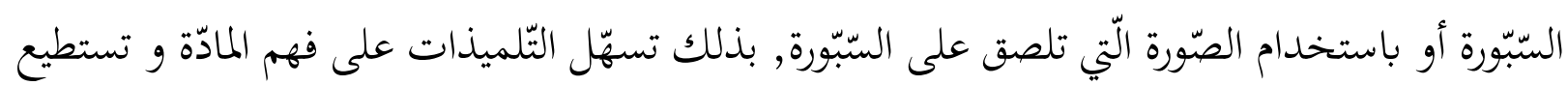

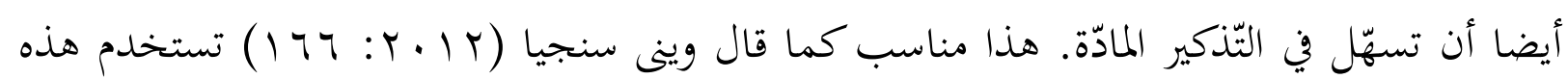
الإستراتيجيّة الصّور كوسائل التّعليميّة. الصّور هي الوسائل العام يستخدم لأنواع المختلفة في عمليّة

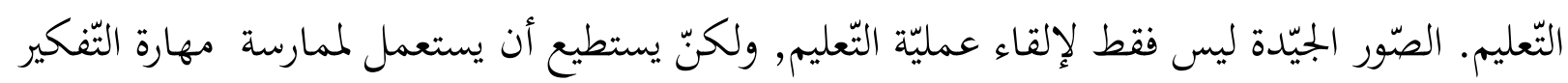

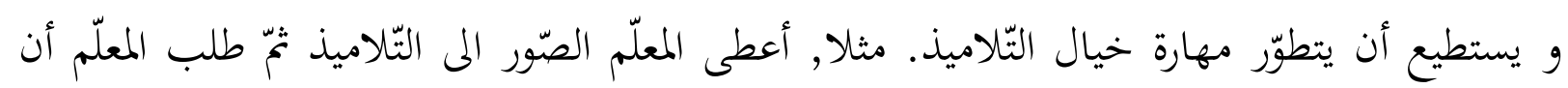

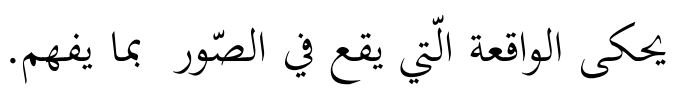

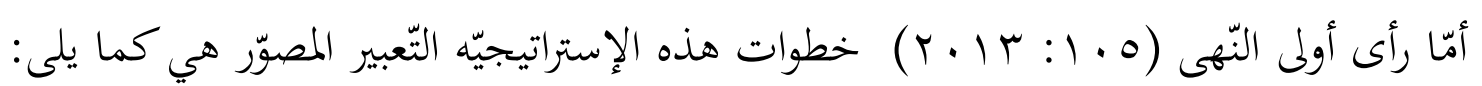

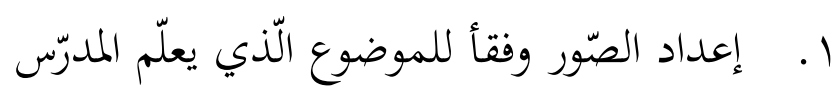

$$
\begin{aligned}
& \text { r. التّصق الصّورة على السّبّورة }
\end{aligned}
$$




$$
\begin{aligned}
& \text { r. يشرح المعلّم الأشياء الموجودة, مع الموضوع الّذي سوف يبحث }
\end{aligned}
$$

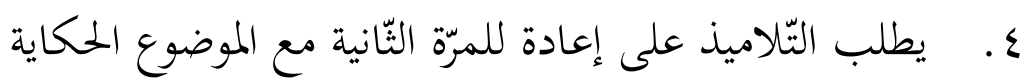

إستنادا من الملاحظة, عرفت الباحثة خطوات تنفيذ إستراتيجيّة التّعبير المصوّر في تعليم المطالعة

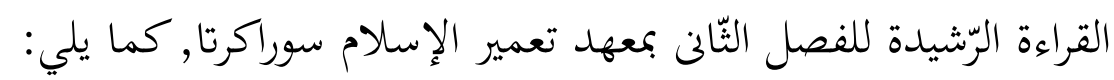

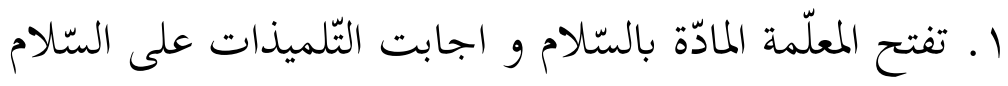

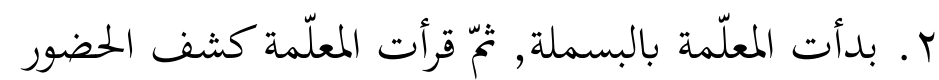

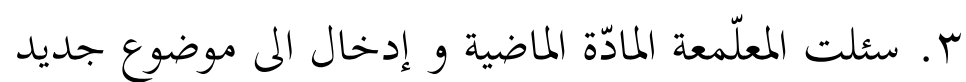

ع. قرأت المعلّمة المفردات بصوت عال و التّلميذة تخمن على المفردات

هـ شرحت المعلّمة المادّة بوسائل التّعليميّة كالصّورة على السّبّورة

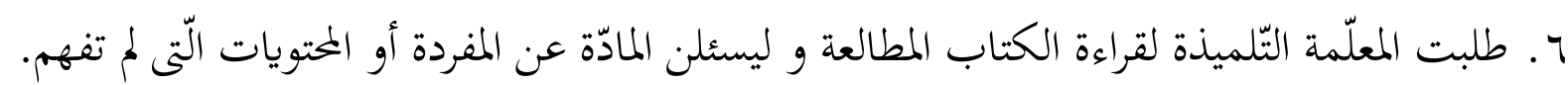

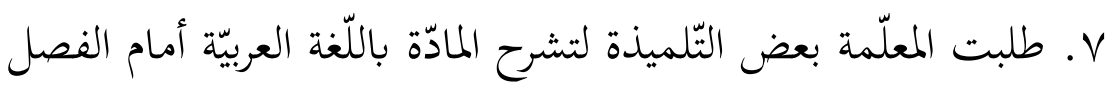

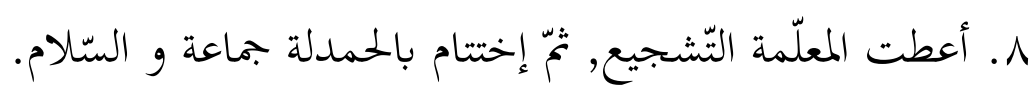

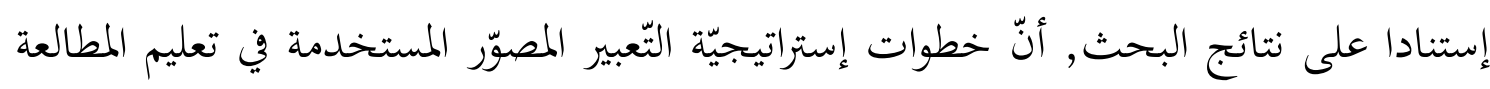

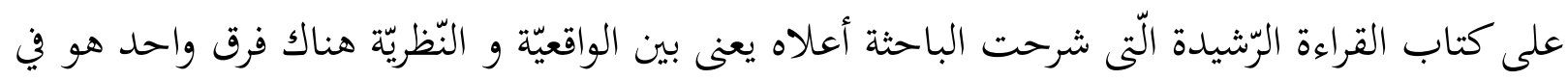

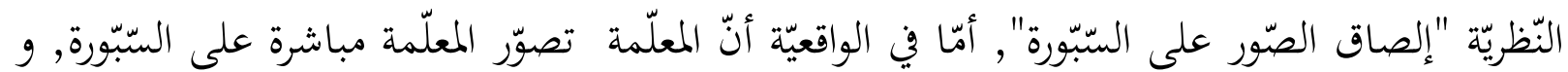
نادرا تلصق المعلّمة الصّورة على السّبّورة.

و من الملاحظة التّى وجدت بالباحثة عند تعليم المطالعة, تستمتع التّلميذات بعمليّة تعليم المطالعة

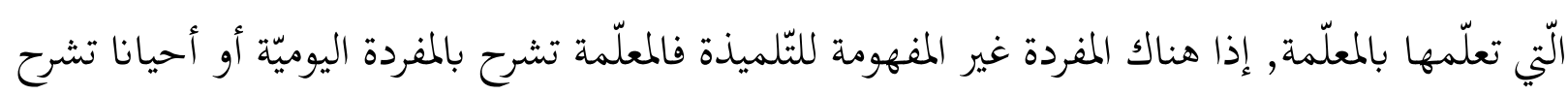

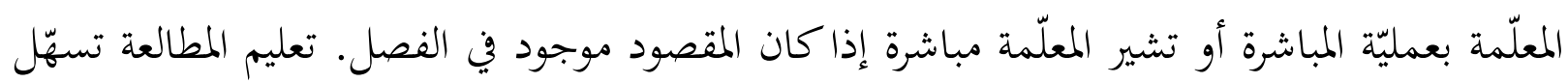

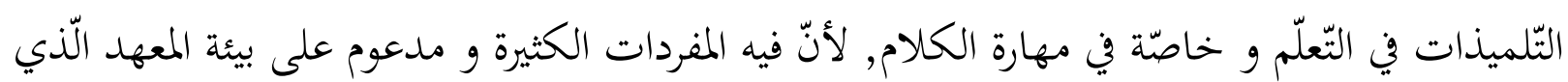
يجب على كلّ التّلميذات أن يستخدمن اللّغة العربيّة في اليوميّة.

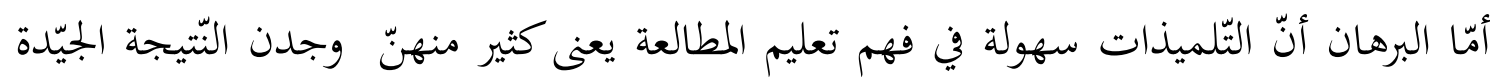

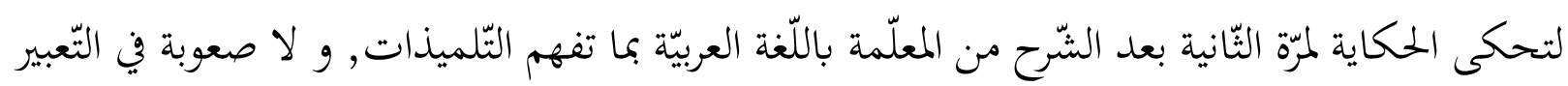




$$
\text { نتائج هذا البحث كما يلى: }
$$

ا ـ خطوات التّبير المصوّر في تعليم المطالعة على كتاب القراءة الرّشيدة, كما يلى:

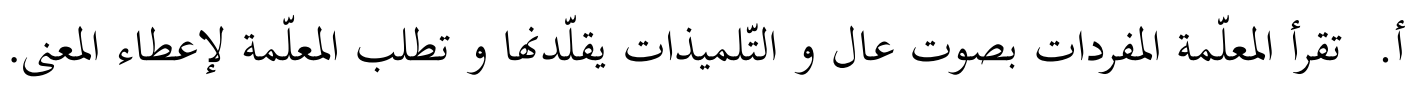

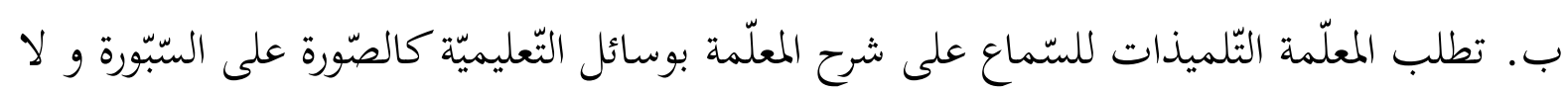

$$
\text { يجوز على التّميذات لفتح الكتب. }
$$

ج. تطلب المعلّمة التّلميذات لقراءة كتاب الممطالعة و إعطاء الوقت الى التّلميذات ليسئلن عن

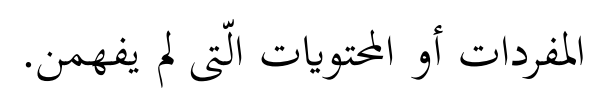

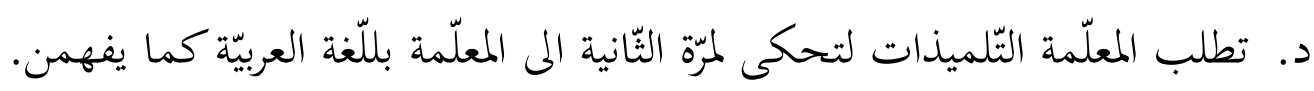

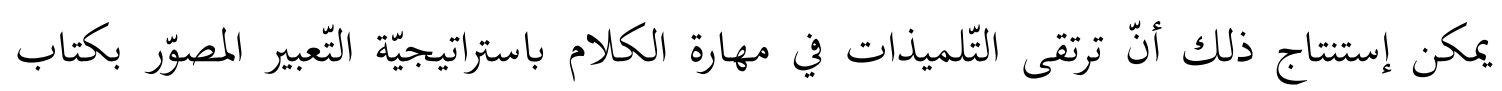

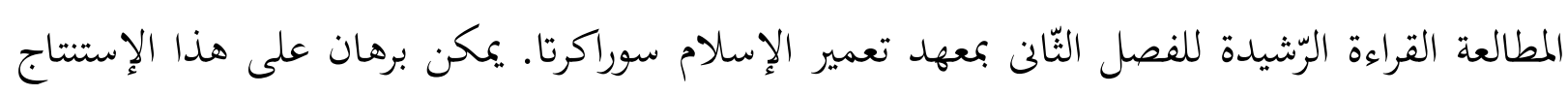

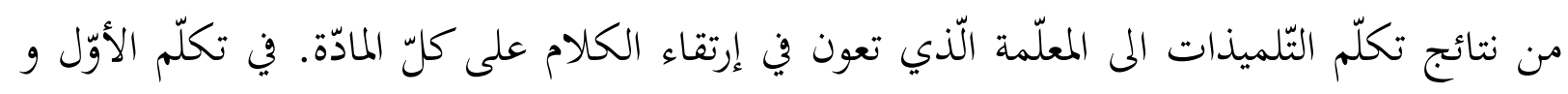

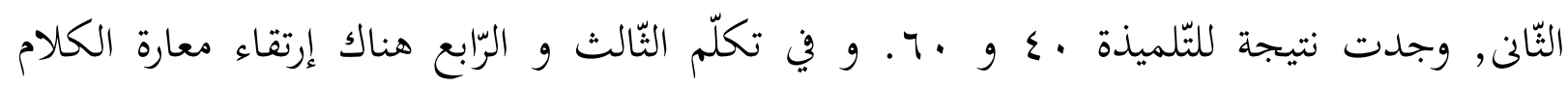

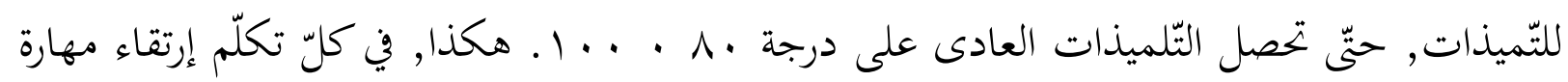
الكلام للتّميذات.

فبتنفيذ إستراتيجيّة التّعبير المصوّر في تعليم المطالعة القراءة الرّشيدة تساعد التّميذات في تذكير

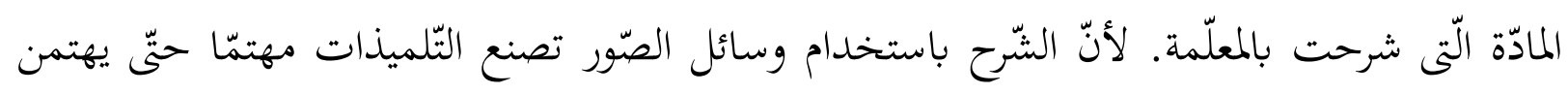

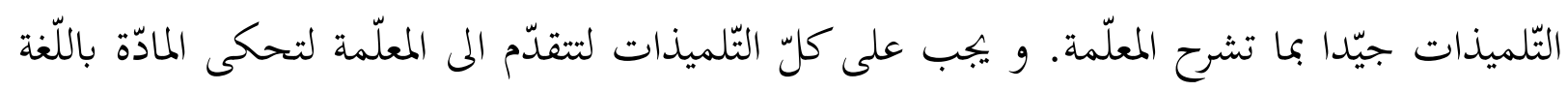
العربيّة بما يفهمن, و . هذا تدريب التّميذات في الكلام و يستميع لترقية مهارة الكلام للتّلميذات. 


\section{المراجع}

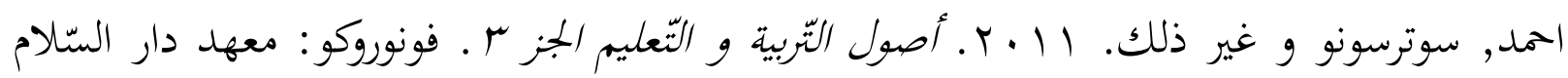
كونتور.

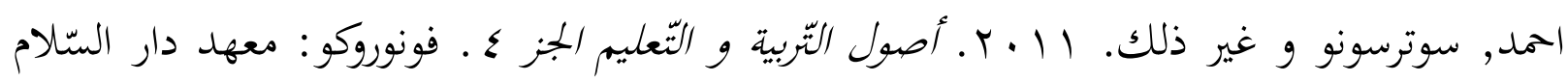
كونتور.

الجيورى, عمران جاسم. rا • ץ. المناهج و طرائق تدريس اللّغة العربيّة. العراق: مؤسّسة دار الصّادف النّقافيّة.

$$
\text { الدّليمى, طه. } 9 \text {. . . . . تدربي اللّغة العربيّة بين الطّرائق. إربد: علم المكتبة الحديث. }
$$

الدّليمى, طه. r. . r. الطّرائق العلميّة في تلدريس اللّغة العببِية. عمان: دار الشّروق للنّشر و التّوزيع.

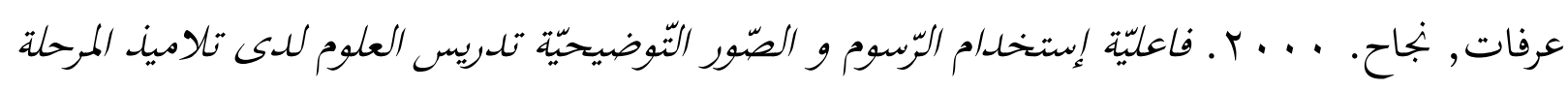
الإعداديّة ذوي النّشاط النّائل على التّحصيل و اكتساب بعض عمليّات العلم. مجلّة التّبيّة

$$
\text { العلميّة. مصر: الدّقهليّة, المجلّد ب, العدد ب. }
$$

نور حزب اللّ, و غيره. 9 ا ـ ץ. المؤتمر الدّولِّ الأولى اللّغة العربيّة و أدابها "خريجو قسم اللّغة العربيّة و

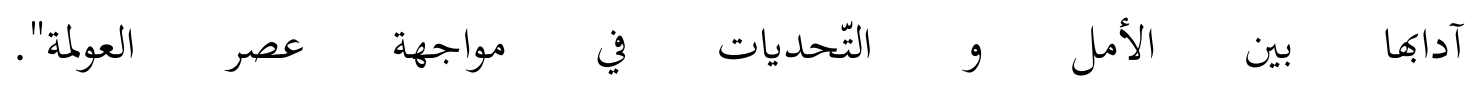
http://digilib.uinsgd.ac.id/id/eprint/13205

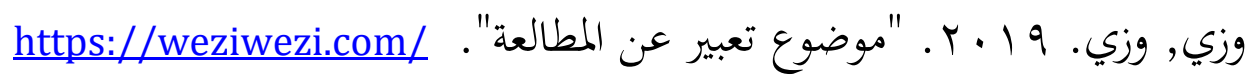

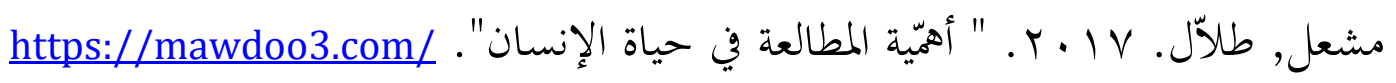
https://mawdoo3.com/ مشعلة, فاطمة. 11 ا • . " "مفهوم مهارة الكلام" ألفة, مطيعة. 0 ا ـ ץ. "ملخّص عن التّبير المصوّر". Anshori, Ahmad Muhtadi. 2009. Pengajaran Bahasa Arab Media dan Metode-metodenya. Yogyakarta: Teras.

Arsyad, Azhar. 2004. Bahasa Arab dan Metode pengajarannya . Yogyakarta: Pustaka Pelajar. Arsyad, Azhar. 2004. Media Pembelajaran. Jakarta: PT Raja Grafindo Persada. 
Asyrofi, Syamsyuddin dan Toni Pransiska. 2016. Penulisan Buku Teks Bahasa Arab. Yogyakarta: Anggota Ikapi.

Hendri, Muspika. 2017. Pembelajaran ketrampilan Berbicara Bahasa Arab Melalui Pendekatan Komunikatif. Jurnal Kependidikan Islam. 3 (2): 199-200

Hermawan, Acep. 2011. Metodologi Pembelajaran Bahasa Arab. Bandung: PT remaja Rosdakarya.

Izzan, Ahmad. 2015. Metodologi Pembelajaran Bahasa Arab. Bandung: Humaniora.

Iskandarwasih dan Dadang Sunendar. 2013. Strategi Pembelajaran Bahasa. Bandung: PT remaja Rosdakarya.

Mustofa, Syaiful. 2011. Strategi Pemelajaran Bahasa Arab Inovatif. Malang: UIN Maliki Press (Anggota Ikapi).

M, Khalilullah. 2012. Media Pembelajaran Bahasa Arab. Yogyakarta: Aswaja Pressindo.

Moleong, Lexy J. 2014. Metodologi Penelitian. Bandung: Remaja Rosdakarya.

Nuha, Ulin. 2012. Metodologi Super Efektif Pembelajaran Bahasa Arab. Yogyakarta: Diva Press.

Rosyidi, Abdul Wahab dan Mamlu'atul Ni'mah. 2012. Memahami Konsep Dasar Pembelajaran Bahasa Arab. Malang: UIN Maliki Press.

Rosyidi, Abdul Wahab. 2009. Media Pembelajaran Bahasa Arab. Malang: UIN Malang Press. Sanjaya, Wina. 2012. Buku Media komunikasi Pembelajaran. Jakarta: Kencana.

Sadiman, Arief S. 1996. Media Pendidikan Pengertian, pengembangan, dan Pemanfaatannya. Jakarta: PT Raja Grafindo Persada.

Sukmadinata, Nana Syaodih. 2011. Metode Penelitian Pendidikan. Bandung: PT Remaja Rosdakarya.

Setiyadi, Bambang. 2006. Penelitian Untuk Pengajaran Bahasa Asing. Yogyakarta: Graha Ilmu.

Tarigan, Henry Guntur. 1994. Berbicara Sebagai Kertrampilan Berbahasa. Bandung: Angkasa.

Triyono. 2012. Metodologi Penelitian Pendidikan. Yogyakarta: Ombak.

Wiriaatmadja, Rochiati. 2008. Metode Penelitian Tindakan Kelas. Bandung: PT Remaja Rosdakarya.

Zulhannan. 2014. Teknik Pembelajaran Bahasa Arab Interaktif. Jakarta: PT Raja Grafindo Persada. 